\title{
The deep Earth origin of the Iceland plume and its effects on regional surface uplift and subsidence
}

\author{
Nicholas Barnett-Moore $^{1}$, Rakib Hassan ${ }^{1}$, Nicolas Flament ${ }^{1, a}$, and Dietmar Müller ${ }^{1}$ \\ ${ }^{1}$ Earthbyte Group, School of Geosciences, The University of Sydney, Sydney, NSW 2006, Australia \\ ${ }^{a}$ now at: School of Earth and Environmental Sciences, University of Wollongong, Northfields Avenue, \\ Wollongong, NSW 2522, Australia
}

Correspondence to: Nicholas Barnett-Moore (nicholas.barnett-moore@sydney.edu.au)

Received: 12 August 2016 - Discussion started: 26 August 2016

Revised: 23 January 2017 - Accepted: 23 January 2017 - Published: 23 February 2017

\begin{abstract}
The present-day seismic structure of the mantle under the North Atlantic Ocean indicates that the Iceland hotspot represents the surface expression of a deep mantle plume, which is thought to have erupted in the North Atlantic domain during the Palaeocene. The spatial and temporal evolution of the plume since its eruption is still highly debated, and little is known about its deep mantle history. Here, we use palaeogeographically constrained global mantle flow models to investigate the evolution of deep Earth flow beneath the North Atlantic since the Jurassic. The models show that over the last $\sim 100 \mathrm{Myr}$ a remarkably stable pattern of convergent flow has prevailed in the lowermost mantle near the tip of the African Large Low-Shear Velocity Province (LLSVP), making it an ideal plume nucleation site. We extract model dynamic topography representative of a plume beneath the North Atlantic region since eruption at $\sim 60 \mathrm{Ma}$ to present day and compare its evolution to available offshore geological and geophysical observations across the region. This comparison confirms that a widespread episode of Palaeocene transient uplift followed by early Eocene anomalous subsidence can be explained by the mantle-driven effects of a plume head $\sim 2500 \mathrm{~km}$ in diameter, arriving beneath central eastern Greenland during the Palaeocene. The location of the model plume eruption beneath eastern Greenland is compatible with several previous models. The predicted dynamic topography is within a few hundred metres of Palaeocene anomalous subsidence derived from well data. This is to be expected given the current limitations involved in modelling the evolution of Earth's mantle flow in 3-D, particularly its interactions with the base of a heterogeneous
\end{abstract}

lithosphere as well as short-wavelength advective upper mantle flow, not captured in the presented global models.

\section{Introduction}

The Iceland hotspot is widely recognised as the surface expression of a deep mantle plume, originating from the coremantle boundary (Morgan, 1971), erupting in the North Atlantic during the Palaeocene (Saunders et al., 1997; White and McKenzie, 1989). At present day, its buoyancy flux is estimated to be the largest of all plumes on Earth (Crosby and McKenzie, 2009), with its evolution believed to have played a significant role in the complex continental breakup history of the northeastern Atlantic (Skogseid et al., 2000) and the formation of $\mathrm{V}$-shaped ridges preserved within the thick oceanic crust that characterises the unique seafloor spreading regime of the region (Parnell-Turner et al., 2014; Smallwood and White, 2002; White et al., 1995). Extrusive volcanics peppered across isolated parts of the northeastern Atlantic have been dated and linked to the arrival and relative motion of the Iceland plume beneath the region (Tegner et al., 2008; Storey et al., 2007; Saunders et al., 1998; Upton et al., 1995; Noble et al., 1988). In addition, numerous offshore efforts have focused on investigating the spatial and transient evolution of the plume since its eruption using tectonic subsidence analysis in Mesozoic basins across the region, which identify either (1) an absence of thermal subsidence during the Palaeocene (Clift and Turner, 1995, 1998), (2) an anomalous increase in subsidence during the Eocene (Stoker, 1997; Joy, 1992), or (3) preserved Palaeocene tran- 
sient uplift (Fletcher et al., 2013; Clift and Turner, 1998). Previous seismic studies support these findings, interpreting Palaeocene unconformities buried by deep-water sediment during the Eocene, reflecting the transient effects of a mantle plume (Champion et al., 2008; Smallwood and Gill, 2002; Clift, 1996). Onshore, fission track studies that constrain denudation histories (Green, 2002; Lewis et al., 1992) suggest that exhumation across northern England can be explained by topographic doming over a mantle hotspot (Lewis et al., 1992). The motion path of the Iceland plume is elusive as large ice sheets over Greenland currently mask geological evidence that could potentially resolve this debate (Rogozhina et al., 2016). Endmember plume motion paths have been proposed (see Rogozhina et al., 2016 for a discussion) based on a moving hotspot reference frame constrained by the hotspots in the Indo-Atlantic oceans (O'Neill et al., 2005) or, alternatively, constrained by hotspots in the Indo-Atlantic and Pacific oceans (Doubrovine et al., 2012). Nevertheless, the understanding of the time-dependent evolution of the deep Earth convective engine beneath the region before $60 \mathrm{Ma}$ remains limited.

Over the last $300 \mathrm{Myr}$ the majority of plumes appear to have originated at the edges of two pronounced LLSVPs beneath Africa and the Pacific Ocean (Doubrovine et al., 2016; Burke et al., 2008). The root of the Iceland plume lies near the tip of the African LLSVP, underlain by ultra-lowvelocity zones (Rost and Earle, 2010) just above the coremantle boundary (CMB; French and Romanowicz, 2014; He et al., 2015). Figure 1 shows the present-day Iceland plume in three dimensions as imaged by the tomography model of French and Romanowicz (2014), which is surrounded by higher than average shear wave velocities in the lowermost mantle as shown in He et al. (2015). Previous mantle flow models show that the morphology of the LLSVPs is modulated by subduction-induced flow in the lowermost mantle (Bower et al., 2013; Hassan et al., 2015, 2016). These results indicate that considering the time-dependent evolution of the lower mantle beneath the North Atlantic and the contributions of subduction-induced flow in the vicinity may shed more light on the spatial and the temporal evolution of the Iceland plume.

Here, we analyse the evolution of global mantle flow in a series of palaeogeographically constrained geodynamic models (e.g. Hassan et al., 2015, 2016). We focus on the deep Earth origins and near-surface arrival of major model plumes beneath the North Atlantic region, and compute and compare the motion path of these model plumes through time (Fig. 2). To understand the deep mantle source of the Iceland plume beneath the North Atlantic, we analyse the mean flow patterns in a $300 \mathrm{~km}$ thick shell above the CMB and evaluate the stability of the northernmost edges of the African LLSVP over time (Fig. 2).

Since models' plumes erupting in the North Atlantic do not exactly match the arrival of the Iceland plume in space-time, we apply an innovative approach - described in
Table 1. Model parameters.

\begin{tabular}{llrl}
\hline Parameter & Symbol & Value & Units \\
\hline Rayleigh number & $R a$ & $5 \times 10^{8}$ & - \\
Earth radius & $R_{0}$ & 6371 & $\mathrm{~km}$ \\
Density & $\rho_{0}$ & 3930 & $\mathrm{~kg} \mathrm{~m}^{-3}$ \\
Thermal expansivity & $\alpha_{0}$ & $1.42 \times 10^{-5}$ & $\mathrm{~K}^{-1}$ \\
Thermal diffusivity & $\kappa_{0}$ & $1 \times 10^{-6}$ & $\mathrm{~m}^{2} \mathrm{~s}^{-1}$ \\
Specific heat capacity & $C_{p}$ & 1100 & $\mathrm{Jkg}^{-1} \mathrm{~K}^{-1}$ \\
Gravitational acceleration & $g$ & 10 & $\mathrm{~ms}^{-2}$ \\
Surface temperature & $T_{\mathrm{S}}$ & 300 & $\mathrm{~K}$ \\
Dissipation number & $D i$ & 0.8 & - \\
Reference viscosity & $\eta_{0}$ & $1 \times 10^{21}$ & $\mathrm{PaS}$ \\
Internal heating & $H$ & 100 & - \\
\hline
\end{tabular}

Sect. 3.2 - to synthesise dynamic topography evolution associated with the Iceland plume, which we then compare to available geological and geophysical observations in the region, including published tectonic subsidence curves (Jones et al., 2001; Clift and Turner, 1998; Clift et al., 1998), analytically modelled transient uplift histories (Hartley et al., 2012), stratigraphically modelled uplift histories (Nadin et al., 1995), and published locations of plume-related extrusive volcanics (as compiled in Torsvik et al., 2001 and updated in Torsvik et al., 2015).

\section{Methods}

\subsection{Numerical models of mantle convection}

We devise numerical models of convection within the Earth's mantle under the extended-Boussinesq approximation (Christensen and Yuen, 1985). The Earth's mantle is modelled as a spherical shell with depth-dependent thermodynamic properties and temperature- and depth-dependent rheology, where the deepest lower mantle is chemically heterogeneous. We solve the equations for the conservation of mass, momentum and energy using the parallel finiteelement code CitcomS (Zhong et al., 2008), which has been extended to allow for assimilation of surface plate motion and subducting slabs derived based on global plate reconstructions (Bower et al., 2015).

The underlying assumptions and the choice of model parameters employed have been outlined in earlier work (Hassan et al., 2015; Bower et al., 2015). Table 1 lists important model parameters and additional details can be found in Hassan et al. (2015).

\subsection{Model setup}

The spherical mesh representing the Earth's mantle comprises $\approx 12.6$ million mesh elements, where radial mesh refinement provides a vertical resolution of $\approx 15$ and $\approx 27 \mathrm{~km}$ near the top and bottom boundary layers, respectively. The temperature decreases by $1225 \mathrm{~K}$ in both the top and the bot- 


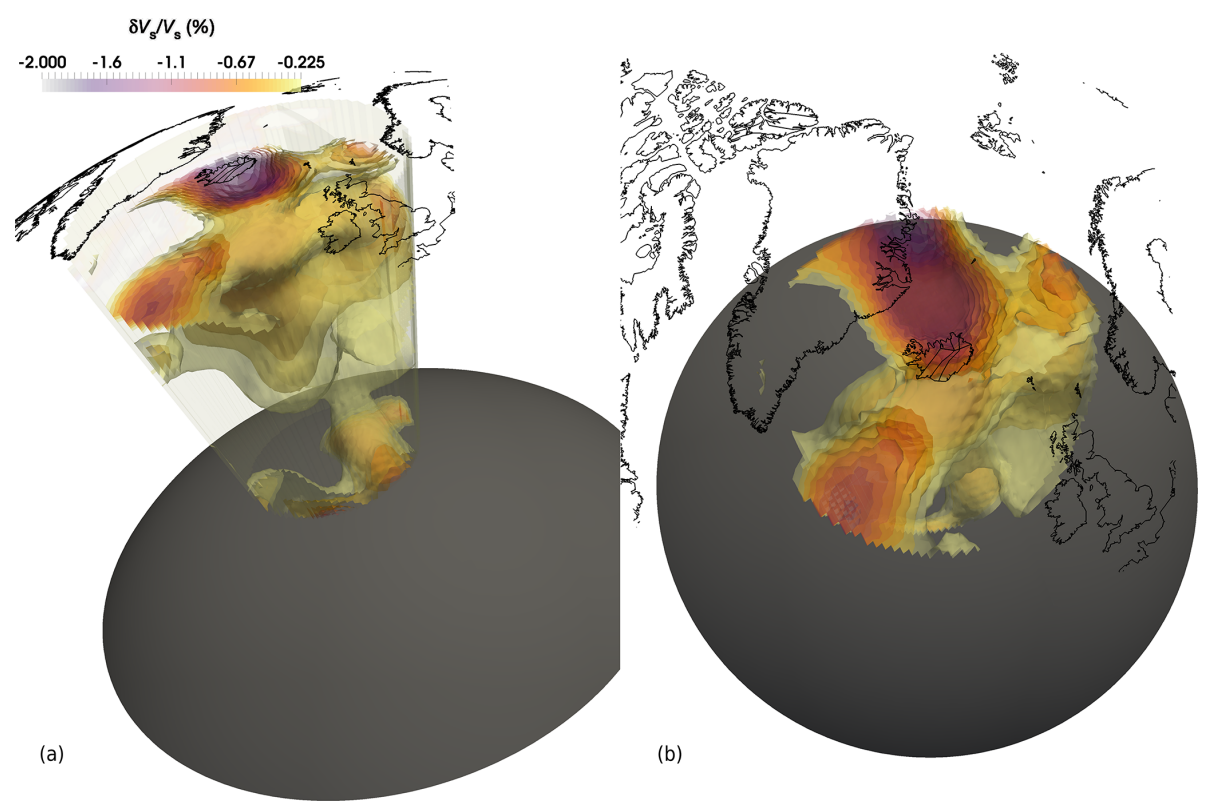

Figure 1. (a) Shear velocity $\left(V_{\mathrm{S}}\right)$ variations in model SEMUCB-WM1 (French and Romanowicz, 2014), within a radius of $\sim 1500 \mathrm{~km}$ from the present-day Iceland plume, extending from $200 \mathrm{~km}$ below the surface to the CMB, are iso-surfaced at intervals of 0.25 , within the range shown. The Iceland plume can be clearly seen emerging from the deep lower mantle, and extending down to the CMB (grey shell). (b) Same as in (a), but shown from a different 3-D perspective to better highlight the shear velocity distribution below the surface.

tom thermal boundary layers. Away from the thermal boundary layers, we assume an a priori mantle adiabat with a potential temperature of $1525 \mathrm{~K}$. In all model cases we specify a non-dimensional internal heat generation rate of 100 and a reference profile for thermal expansion based on analytical parameterisations given in Tosi et al. (2013).

We use piecewise Arrhenius laws to describe the variation in viscosity with temperature, depth and composition in the Earth's mantle, which takes the following non-dimensional form:

$$
\begin{aligned}
\eta(T, r) & =A(r) \eta_{\mathrm{c}} \exp \left(\frac{E_{\mathrm{a}}(r)+(1-r) V_{\mathrm{a}}(r)}{T+T_{\mathrm{off}}}\right. \\
& \left.-\frac{E_{\mathrm{a}}(r)+\left(1-r_{\text {inner }}\right) V_{\mathrm{a}}(r)}{1+T_{\text {off }}}\right),
\end{aligned}
$$

where $\eta$ is the viscosity, $T$ is the temperature, $r$ is the radius, $A$ is the pre-exponential parameter, $\eta_{\mathrm{c}}$ is the intrinsic composition-dependent pre-factor, $E_{\mathrm{a}}$ is the activation energy, $V_{\mathrm{a}}$ is the activation volume and $T_{\text {off }}$ is the temperature offset. For the lower mantle, we use a dimensional activation energy of $320 \mathrm{KJ} \mathrm{mol}^{-1}$ and activation volume of $6.7 \times 10^{-6} \mathrm{~m}^{3} \mathrm{~mol}^{-1}$, corresponding to non-dimensional units of 11 and 26, respectively, which are comparable to estimates in Karato and Wu (1993). However, since such viscosity parameterisations lead to large viscosity variations that cause numerical difficulties, we adjust the pre-exponential parameter $A(r)$ and the temperature offset $T_{\text {off }}$ (Tackley, 1996) to limit the viscosity contrast to 3 orders of magnitude.
The resulting viscosity profile is similar to the preferred viscosity profiles of Steinberger and Calderwood (2006). Additional details on model setup can be found in Hassan et al. (2015).

The initial condition at $230 \mathrm{Ma}$ includes slabs inserted from the surface down to $1200 \mathrm{~km}$ depth, and an anomalously dense thermochemical layer of uniform thickness at the base of the mantle. We apply kinematic surface boundary conditions based on surface velocities derived from global plate tectonic reconstructions at one million year intervals, with a linear interpolation in between. We assimilate thermal models of inferred subducting slabs into the dynamically evolving temperature field at each timestep, as the model progresses towards present day, starting from a given geological time (see Bower et al., 2015, for more detail).

\subsection{Computation of dynamic topography}

We compute time-dependent dynamic topography, $h$, at the surface at $5 \mathrm{Myr}$ intervals as

$h=\frac{\sigma_{\mathrm{rr}}}{\Delta \rho g}$,

where $\sigma_{\text {rr }}$ and $\Delta \rho$ are the radial component of stress and the density difference between the mantle and the overlying material, respectively. The radial stresses, $\sigma_{\mathrm{rr}}$, are recomputed using Stokes flow and the temperature field at a given time. We exclude buoyancy in the top $350 \mathrm{~km}$ of the mantle in the Stokes flow computations in order to remove the influence of 
(a)

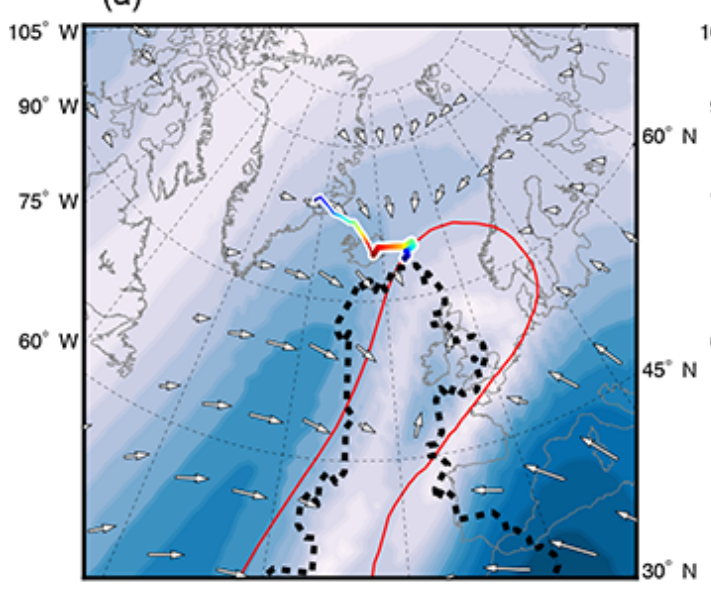

(c)

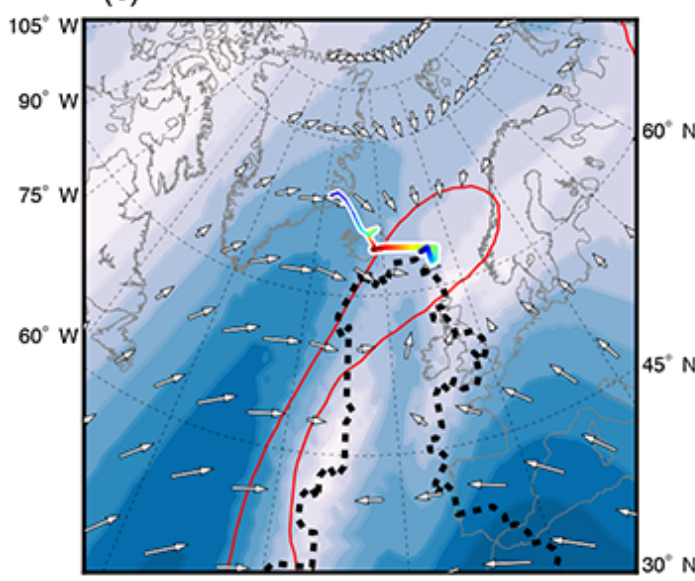

(b)

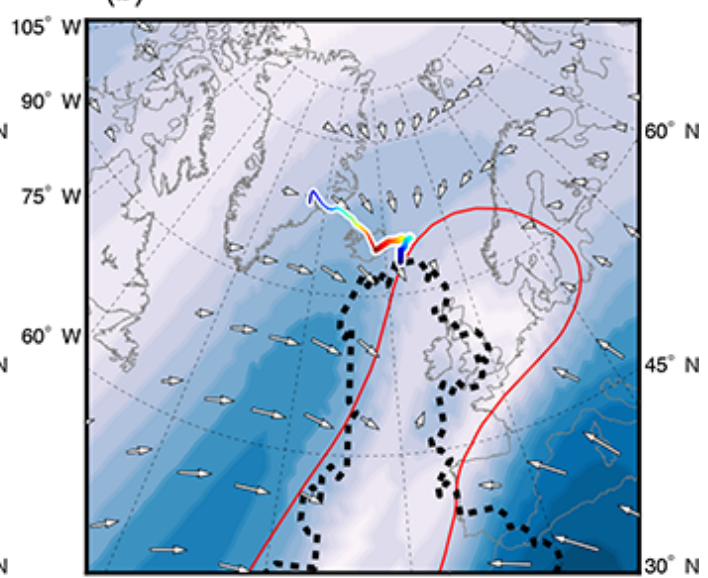

(d)
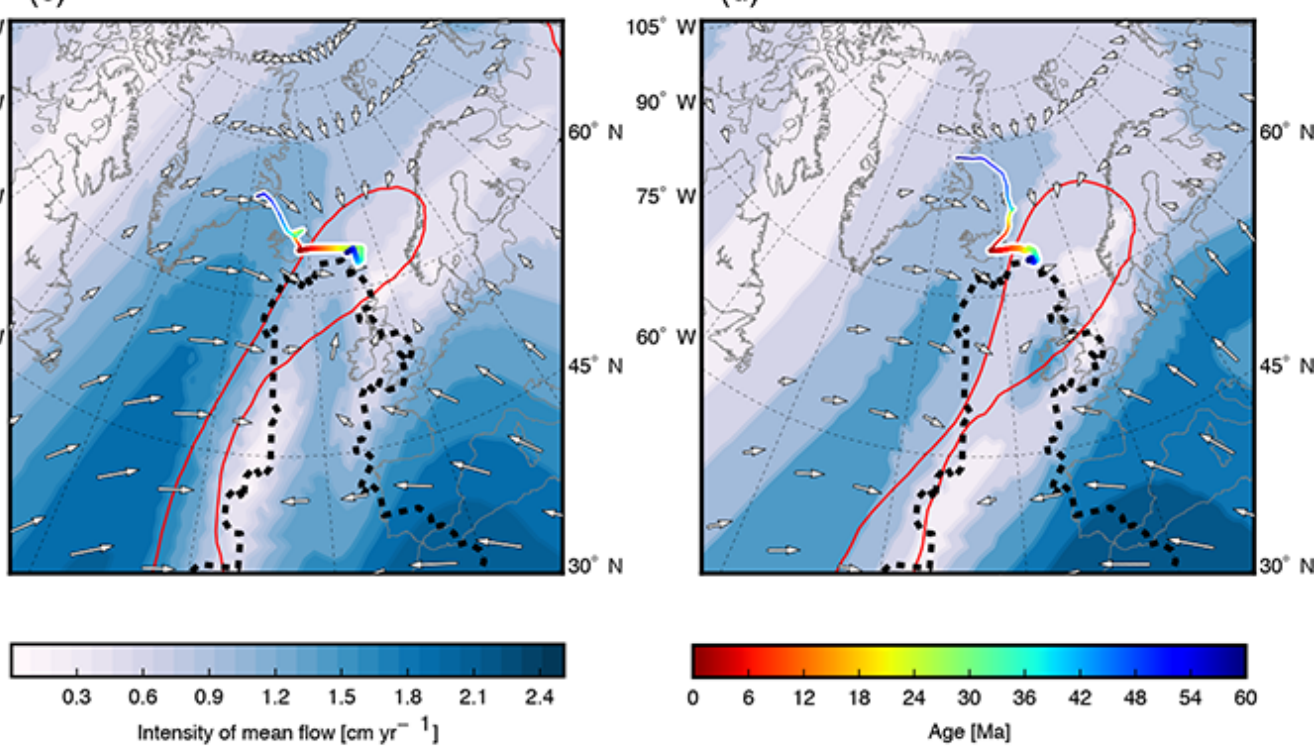

$2.5 \mathrm{~cm} \mathrm{yr}^{-1}$

Figure 2. (a) In model case $\mathrm{C} 1$ (Table 2), the magnitude of mean flow velocity in a $300 \mathrm{~km}$ thick shell above the CMB, time-averaged over the last $100 \mathrm{Myr}$ is shown in grey shading and associated flow directions are shown by white arrows. Flow directions are not shown for regions where flow magnitudes are smaller than their standard deviation, $\sigma$, to avoid visual clutter. The $75 \%$ chemical concentration isosurface of the dense chemical layer above the CMB, time-averaged over the last $100 \mathrm{Myr}$, defines the mean location of model LLSVPs over the period. The red contour shows the mean location of the edges of the northern tip of model African LLSVP, $200 \mathrm{~km}$ above the CMB. The black contour marks the region classified in four out of five tomography models to have a slower than average shear velocity in the lower mantle (Lekic et al., 2012). The thick multi-coloured trajectory shows the motion of the model plume in the mantle frame of reference since its arrival near the surface at $60 \mathrm{Ma}$, while the thin multi-coloured trajectory shows corresponding motion in plate frame of reference - see in text for more details. (b-d) Same as in (a), but for model cases C2-C4, respectively.

assimilated data. Moreover, to exclude the traction induced by kinematic plate velocities (velocity boundary condition at the surface), we impose free-slip boundary conditions at the surface in these Stokes flow computations.

\subsection{Parameter space explored}

We interrogate four models described in Hassan et al. (2015, $2016)$, in which the density contrast $\left(\Delta \rho_{\text {ch }}\right)$ of a dense chemical layer above the CMB, the thickness of the dense layer $(\Delta d)$ and the plate reconstruction that dictates surface plate velocities and the location of subduction zones was varied, keeping all other parameters constant. The kinematic surface 
Table 2. Model cases.

\begin{tabular}{cccr|r}
\hline & \multicolumn{3}{c|}{ Input parameters } & Output parameters \\
\hline Case & $\Delta \rho_{\text {ch }} \%$ & $\begin{array}{l}\text { Tectonic } \\
\text { reconstruction }\end{array}$ & $\Delta d[\mathrm{~km}]$ & $\begin{array}{r}\text { Model plume } \\
\text { eruption age } \\
(\mathrm{Ma})\end{array}$ \\
\hline $\mathrm{C} 1^{\mathrm{a}}$ & 3.0 & APM1 & 100 & 155 \\
$\mathrm{C}^{\mathrm{b}}$ & 3.5 & APM1 & 100 & 155 \\
$\mathrm{C} 3^{\mathrm{c}}$ & 2.5 & APM2 & 100 & 160 \\
$\mathrm{C}^{\mathrm{d}}$ & 2.5 & APM1 & Domed & 120 \\
\hline a, b Models M4 and M5, respectively, in Hassan et al. (2015). ${ }^{\text {c, d }}$ Models M4 and M5,
\end{tabular}

respectively, in Hassan et al. (2016).

boundary condition depends both on the relative plate motion model and the absolute plate motion model. In all model cases, while using the same relative plate motion model, we test the influences of alternative absolute plate motion models (APM1 and APM2) - see Hassan et al. (2016), for a description of the relative and absolute plate motion models used. The dense layer above the CMB in most model cases is of uniform thickness in the initial condition. However, the dense LLSVP material may have already been displaced and deformed by subducted slabs (McNamara and Zhong, 2004; Bower et al., 2013) - to test the influences of a deformed dense layer in the initial condition on model results, we present a model case where the dense layer is initially confined to two domes resembling present-day LLSVPs. These domes are also hotter than the ambient mantle - see Hassan et al. (2016) for more details. Table 2 lists model parameters that vary across the model cases.

Although Hassan et al. (2015) derived spatial correlations of distributions of model plume eruption locations with reconstructed eruption locations of large igneous provinces (LIPs), their study did not account for temporal misfits between model plumes at robust plume nucleation sites and related LIPs. The temporal misfits are partly a consequence of model initiation times and idealised initial conditions adopted due to a lack of constraints on the structure of the mantle in deep geological time and more generally due to the stochastic nature of plume dynamics. Devising forward mantle convection models that reproduce model plume eruptions that match associated LIP eruptions in both space and time would require an elaborate iterative optimisation scheme. The distribution of thermal and compositional heterogeneities in the deep lower mantle would be iteratively constrained in a bid to reduce space-time misfits between model plume eruptions and associated LIPs, which is beyond the scope of this study. Instead, here we compute analytics of flow in the lowermost mantle beneath the North Atlantic Ocean and focus on the general trajectory of the model plume over the last $60 \mathrm{Myr}$ in the different models (Fig. 2).

\section{Deep Earth origin of the Iceland plume and associated dynamic topography evolution}

\subsection{Predicted spatio-temporal evolution of the deep mantle flow beneath the North Atlantic}

Analytics of flow in the lowermost mantle under the north Atlantic reveal a consistent pattern of convergent flow over the last $100 \mathrm{Myr}$, near the tip of the present-day African LLSVP (dotted black contours, Fig. 2). In all models the time-averaged flow directions and contours of the mean location of the model LLSVP (red contours, Fig. 2) over the period also suggests that a stable plume nucleation site already prevailed beneath the North Atlantic, near the present-day Iceland plume, well before its nucleation. Southeasterly flow from the west, northwesterly flow from the east and weaker southerly flow from the north converge in a lowermost mantle at a quasi-stagnation zone under the British Isles (Fig. 2). The mean location of the northern extremity of the model African LLSVP (red contours, Fig. 2) over the last $100 \mathrm{Myr}$ agrees well with present-day tomography (dotted black contours, Fig. 2), although, in model cases $\mathrm{C} 3$ and $\mathrm{C} 4$, the mean location of the model LLSVP necks considerably more at $\sim 45^{\circ} \mathrm{N}$ and is shifted westward compared to those in models $\mathrm{C} 1$ and $\mathrm{C} 2$. Nevertheless, the mean location of the northern tip of the model LLSVP, in all model cases, is generally consistent with the tomography - thus highlighting the robustness of the general trends in the model results and that they are not particularly sensitive to model parameters, within the parameter space explored. In case $\mathrm{C} 2$, the mean location of the model LLSVP has the largest spatial overlap with the tomography - we therefore choose case $\mathrm{C} 2$ as the preferred model.

\subsection{Motion path and dynamic topography signal of model plume}

We extract the absolute motion path of the Iceland model plume based on a plume detection scheme (described in detail in Hassan et al., 2015) that detects all model plumes at a given time instance. The spatial locations of model plumes, throughout the modelled geological time, are then binned together based on spatio-temporal proximity to derive the absolute motion paths (for more details see Hassan et al., 2016). As mentioned in Sect. 2.4, the eruption of the model plume does not coincide in space-time with the associated LIP eruptions in the north Atlantic. The model plume erupts within $\sim 15-20^{\circ}$ of the present-day location of the Iceland plume, but between 60 and $100 \mathrm{Myr}$ earlier than that of the Iceland plume - the eruption ages of the model plume in each model are given in Table 1. Figures 3 and 4 and animation S1 in the Supplement show the evolution of the model plume in the preferred model (C2) since eruption at $150 \mathrm{Ma}$ to present day. 


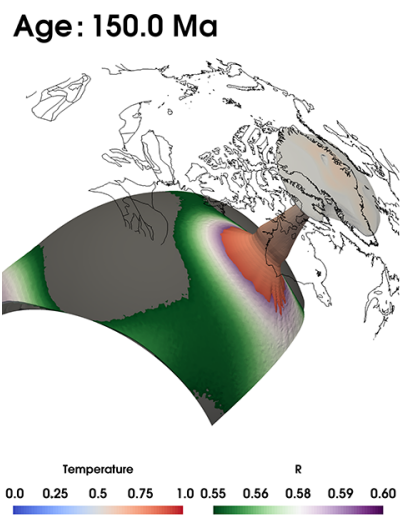

(a)

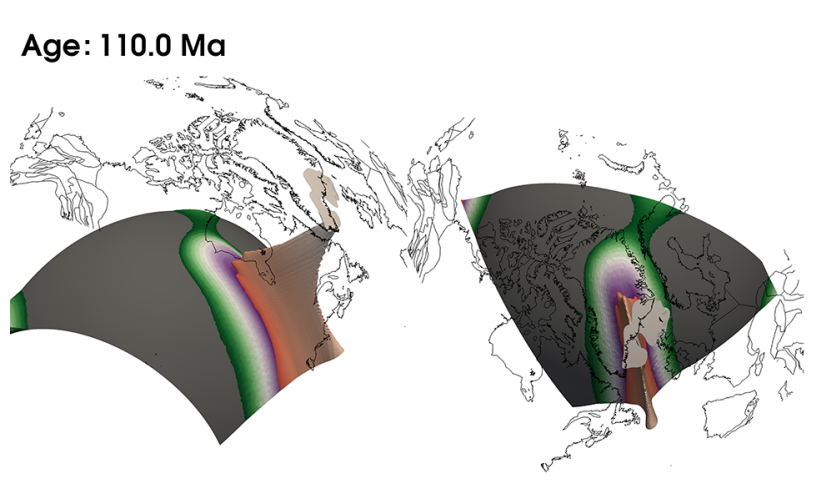

(c)

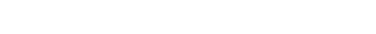

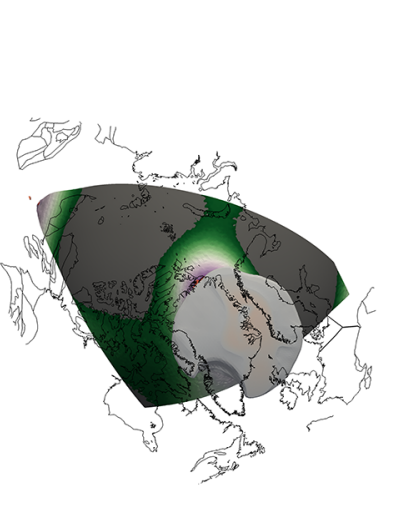

Figure 3. (a) The non-dimensional temperature field above layer averages, $\partial T$ temperature) in the range $0.08-0.3$, delineating the model plume erupting at $150 \mathrm{Ma}$ in case $\mathrm{C} 2$ (see Table 2 ). The top $200 \mathrm{~km}$ is excluded from the rendering to avoid visual clutter. Non-dimensional topography of the $75 \%$ chemical concentration isosurface, above the CMB, is also shown and reconstructed coastlines are shown for geographical reference. (b-d) Same as in (a), but at labelled ages.
In order to glean insights from dynamically evolving, selfconsistent model plumes that can be validated against the observational record, we consider the following: (1) although the model plume in the preferred case at present day it is $\sim 10^{\circ}$ to the southwest away from the location of the Iceland plume as inferred by Torsvik et al. (2015), the trajectory of the model plume over the last $60 \mathrm{Myr}$ is a good proxy for the motion of the Iceland plume over the same period, given their close proximity at present day and the structure of timeaveraged flow in the lowermost mantle (Fig. 2b); (2) consequently, the dynamic topography signal associated with the model plume since eruption at 150 to $90 \mathrm{Ma}$ is also representative of that of the Iceland plume over the last $60 \mathrm{Myr}$. All subsequent analysis presented in this paper are based on these key assumptions, which are reasonable given the current limitations of the models.

The thick multi-coloured trajectories shown in each panel of Fig. 2 correspond to the absolute motion (mantle frame of reference) of the model plume in each model, but rotated such that the model plume arrives at the inferred location of the Iceland plume at present day. It is the same approach as

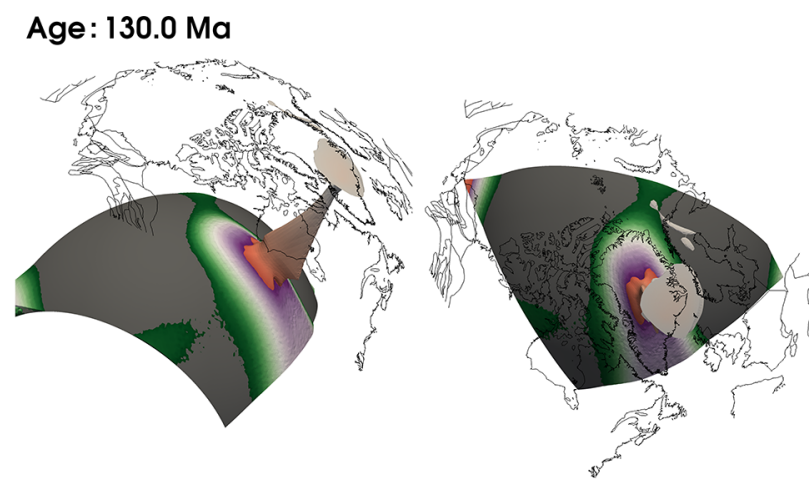

(b)

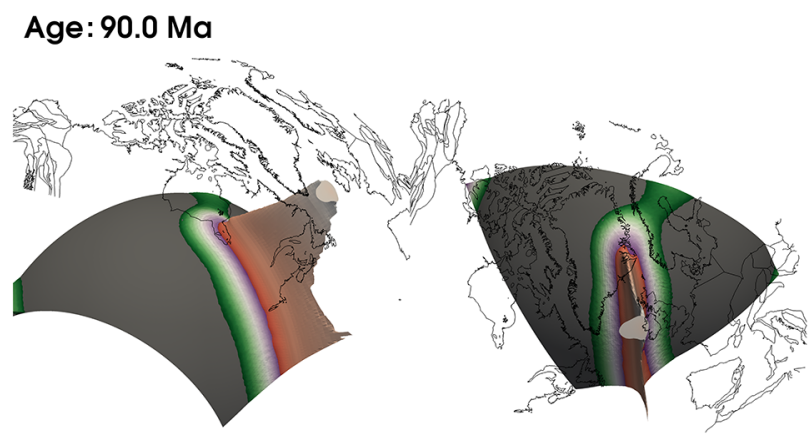

(d) adopted in Hassan et al. (2016) to relate the motion of the model Hawaiian plume to that of the actual plume. Absolute motion paths obtained from the different models demonstrate a general consistency not only across the models presented here but also when compared to motion paths obtained using backward advection models (Fig. 6; Torsvik et al., 2015), such that the net motion of the plume is dominantly westward over the last $60 \mathrm{Myr}$. Based on these absolute motion paths, we also compute the trajectory of the Iceland plume relative to Greenland (thin multi-coloured trajectories shown in each panel of Fig. 2) using GPlates (Boyden et al., 2011), for comparison in this frame of reference (e.g. Rogozhina et al., 2016).

In order to address the space-time offset - based on the assumptions listed above - between the dynamic topography signal associated with the model plume and that of the actual plume, we compute a set of reconstituted dynamic topography grids for the preferred model as follows:

1. Demarcate the dynamic topography signal associated with the model plume, over the last $60 \mathrm{Myr}$ (Fig. 4), 

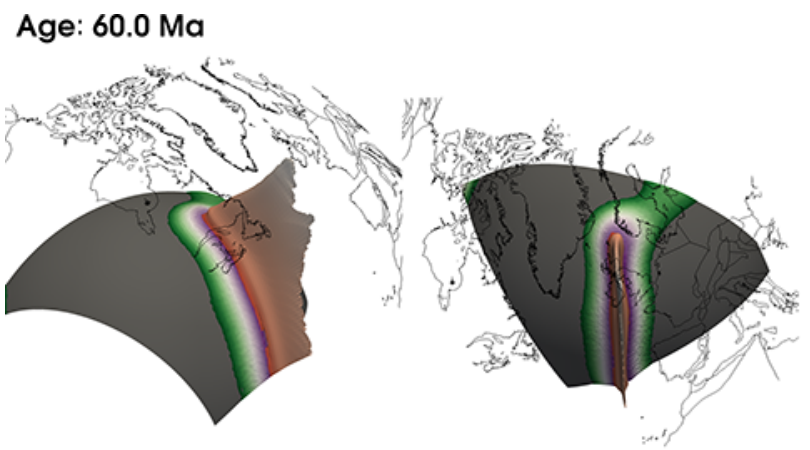

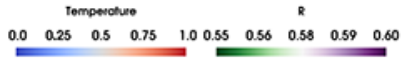

(a)

\section{Age: $20.0 \mathrm{Ma}$}

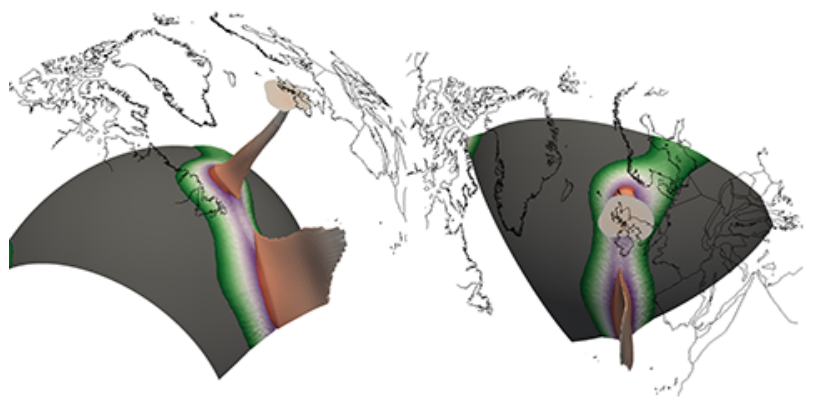

(c)

\section{Age: $40.0 \mathrm{Ma}$}

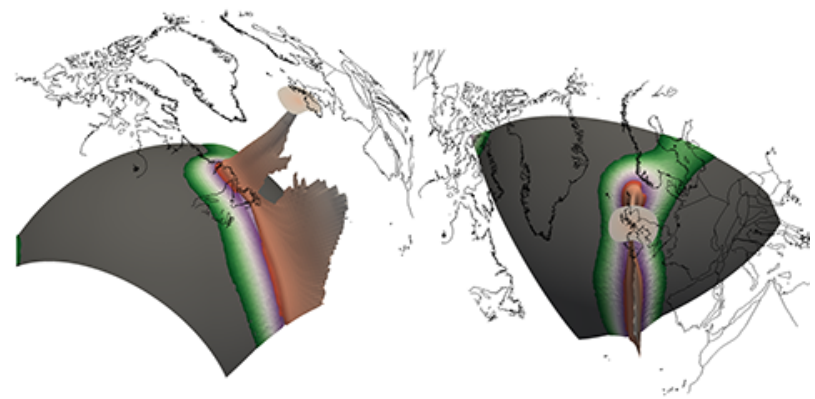

(b)

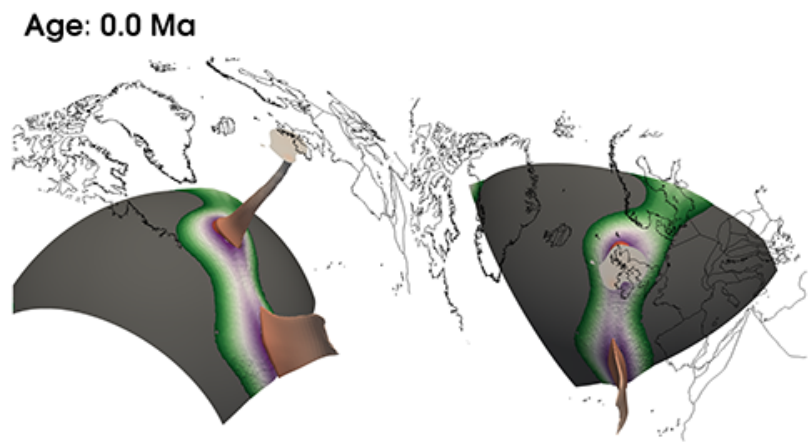

(d)

Figure 4. Same as Fig. 3 but for ages (a) $60 \mathrm{Ma}$, (b) $40 \mathrm{Ma}$, (c) $20 \mathrm{Ma}$, and (d) $0 \mathrm{Ma}$.

with a contour value of 1 standard deviation above the mean $\left(\bar{h}+\sigma_{h}\right)$, within a radius of $2500 \mathrm{~km}$ of the plume axis; exclude it from the global grids; and fill in the resulting voids using a suite of Generic Mapping Tools (GMT) programs (Wessel et al., 2013). In other words the dynamic topography signal associated with the model plume is "surgically" removed.

2. Extract the dynamic topography signal associated with the model plume between eruption at 150 and $90 \mathrm{Ma}$ (Fig. 3) by demarcating the spatial extent of the plume at a given time with a contour value of $\left(\bar{h}+\alpha \sigma_{h}\right)$, within a radius, $r_{\mathrm{p}}$ of the plume axis, where $r_{\mathrm{p}}$ and $\alpha$ are constants that linearly increase between [2.25, 0.35] and [3500, 2000] from 150 to $90 \mathrm{Ma}$, respectively. The values of these constants are chosen such that the gradual weakening of the plume - since eruption - is taken into account. A narrow buffer around the dynamic topography signal of the plume is also demarcated using a contour value of $\left(\bar{h}+\frac{\alpha}{4} \sigma_{h}\right)$ for the purpose of smoothing, as described in the following step.

3. Rotate the dynamic topography signals, along with the buffer regions, extracted in step 2 to the spatial locations along the absolute plume motion path (shown in
Fig. 2b); superpose them on the grids obtained in step 1; and apply spatial smoothing within the buffer regions.

The sequence of steps outlined above, although not ideal, yields a space-time varying dynamic topography signal representative of the Iceland plume, not just in terms of its absolute motion, which is guided by a global flow field in the lowermost mantle, but also in terms of the thermal evolution of the plume, which is expressed in the associated dynamic topography signal. It is important to note that such insights are inaccessible to mantle flow models that employ backward advection based on present-day initial conditions derived from seismic tomography (e.g. Steinberger, 2000; Conrad and Gurnis, 2003; Moucha and Forte, 2011). Backward advection models suffer from fundamental theoretical limitations that restrict the time interval over which they can faithfully reproduce past mantle structures (Ismail-Zadeh et al., 2009). Critically, this time interval is short for conductiondominated heat transfer, such as during the conductive thickening of the lower thermal boundary layer, associated with plume nucleation, or the eruption of a plume head below the lithosphere. In other words, the thermal evolution of a plume and its associated dynamic topography signal throughout its lifetime cannot be captured in backward advection models. 

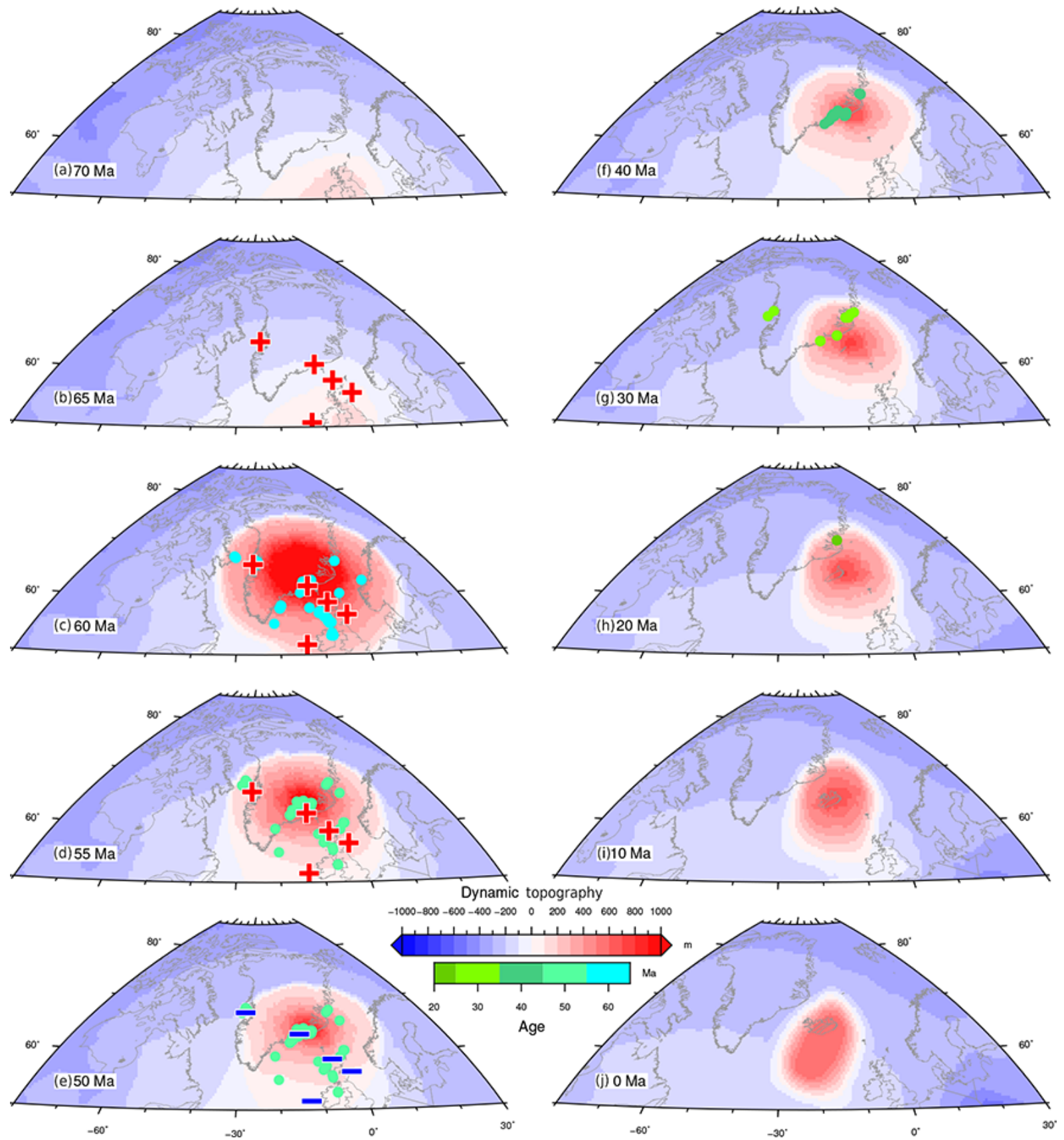

Figure 5. (a-j) Predicted Cenozoic North Atlantic dynamic topography in the mantle frame of reference extracted from the preferred reconstituted mantle flow model discussed in text. Circles colour-coded by age represent a compiled set of extrusive volcanics related to plume activities across the North Atlantic (Spice et al., 2016; Torsvik et al., 2001) in 10 Myr intervals ( \pm 5 Myr for each reconstructed time) and reconstructed in the mantle frame of reference. Positive (red crosses) and negative (blue dashes) signs correspond to the timings in transient uplift and subsequent subsidence, respectively, based on published observations compiled in Figs. 6-9.

Consequently, our efforts here are the first attempts (to our knowledge) to compare the space-time varying dynamic topography signal from a fully dynamic model plume to geological observations associated with the Iceland plume in the North Atlantic Ocean.
The reconstituted dynamic topography grids imply nearsurface arrival ( $\sim 60 \mathrm{Ma})$ of the model plume somewhere beneath central eastern Greenland (Figs. 5-6), near Kangerdlugssuaq (Fig. 7; inset). The surface expression of the plume then migrates southeastward toward the eastern Greenland coastline, arriving there by $\sim 50 \mathrm{Ma}$ (Figs. $5-6$ ). It then con- 


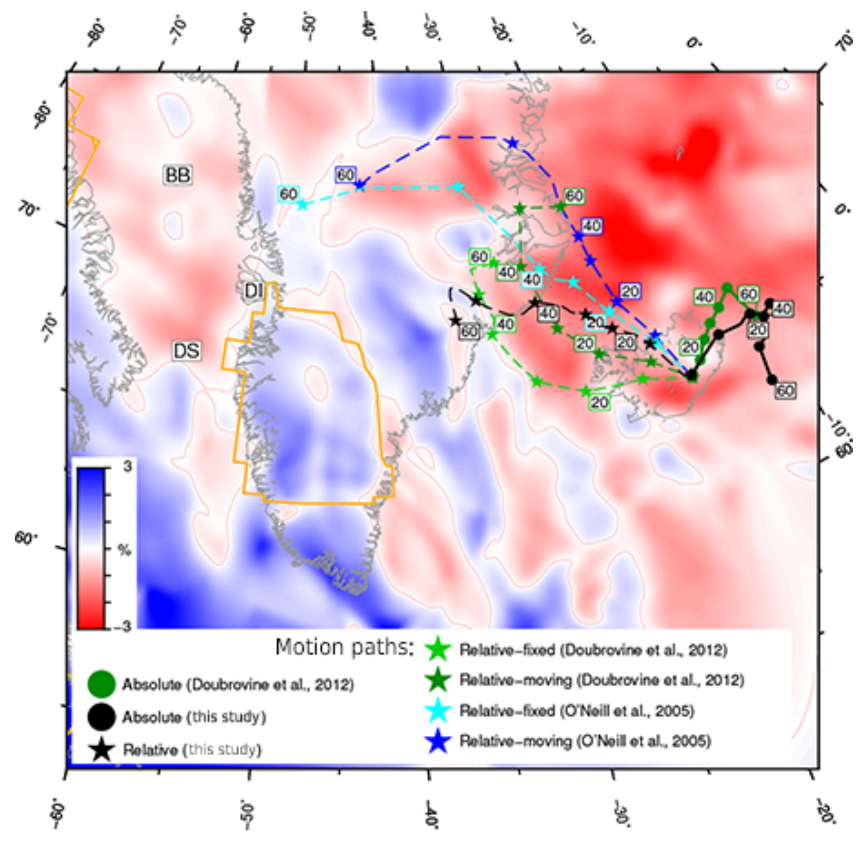

Figure 6. (a) Reconstructed absolute motion paths of the Iceland plume (solid bold circles) and its reconstructed relative motion paths to Greenland (solid smaller stars). Black: model motion paths (Sect. 2.2.3) from this study; green: motion paths of Doubrovine et al. (2012); blue: motion paths of O'Neill et al. (2005). Underlain is the $150 \mathrm{~km}$ depth slice of a $P$ wave velocity model (Jakovlev et al., 2012) presented in Rogozhina et al. (2016), showing the velocity model beneath Baffin Bay and Davis Straight and Greenland, colour-mapped for percentage velocity anomaly. DI: Disko Island; BB: Baffin Bay; DS: Davis Straight.

tinues this southeastward motion path towards the presentday location of its conduit (Fig. 2a). The predicted motion of the model plume is compatible with the spatial and temporal evolution of plume-related magmatism within the North Atlantic (Fig. 5c-h; Torsvik et al., 2015). The evolution of dynamic topography magnitudes through time shows maximum dynamic uplift is spatially largest at $\sim 60 \mathrm{Ma}, \sim 2500 \mathrm{~km}$ in diameter (Fig. 5c; see Fig. 3a for comparison). This is focused beneath central eastern Greenland (Fig. 5), and extends across the entire North Atlantic (Fig. 5c). At this time the effect of the dynamic uplift related to the near-surface arrival of the model plume encompasses parts of the Artic to the north, Baffin Bay to the west, most of the Labrador Sea to the south, and the Norwegian margins and Mesozoic basins lining the northwestern European margin to the east (Fig. 5c). After $\sim 60 \mathrm{Ma}$, the maximum magnitude of this dynamic uplift is greatly diminished, resulting in dynamic subsidence of these surrounding regions until $\sim 30-40 \mathrm{Ma}$ (Fig. 5d-f). By this time, the plume has continued to shrink in extent (Fig. 5g), migrating eastward and beginning to straddle the Norwegian margin and Mesozoic basins along the northwestern European margins (Fig. $5 \mathrm{~g}-\mathrm{j}$ ) of the early northeastern Atlantic Ocean. This results in minor positive dynamic re- bound $(\sim 10-50 \mathrm{~m})$ across these major basins, and then a return to pronounced dynamic subsidence until present day as the plume migrates further eastward and diminishes in magnitude (Fig. 5g-j).

\section{Comparing the predicted Iceland plume motion and associated topography to geological and geophysical observations}

To evaluate the evolution of dynamic topography through time (Sect. 3.2) we assess (1) the absolute and relative motion path of the model plume in the context of previously published plume motion paths (Sect. 4.1), (2) the location and spatial extent affected of its near-surface arrival (Sect. 4.1, 4.2), and (3) its contributions to the regions topographic vertical motions through time via a comparison with tectonic subsidence histories and other related studies (Sect. 4.2).

\subsection{Comparing the plume motion path against previous Iceland plume motion paths}

We compare the absolute motion path of the model plume to previous efforts (Fig. 6) that have derived its motion path through generating new global absolute plate reference frames (e.g. Doubrovine et al., 2012; O'Neill et al., 2005). Doubrovine et al. (2012) proposed a global moving hotspot reference frame from backward advected numerical convection models. This method is constrained by a number of well-studied hotspot tracks in the Indo-Atlantic and Pacific and in global plate reconstructions (Doubrovine et al., 2012). This reference frame challenges the validity of traditional absolute reference frames that assume hotspots are fixed through time (Müller et al., 1993; Morgan, 1971). O'Neill et al. (2005) used Indo-Atlantic hotspot tracks to produce both a fixed and moving hotspot reference frame, and found that the two were nearly indistinguishable over the last $\sim 80 \mathrm{Myr}$, concluding that any hotspot motion within the mantle was not obvious beyond the uncertainties in the data (O'Neill et al., 2005). A key difference between the approach of Doubrovine et al. (2012) and O'Neill et al. (2005) is the number of hotspots used in each study (Torsvik et al., 2015). O'Neill et al. (2005) only considered the IndoAtlantic hotspots, whereas Doubrovine et al. (2012) included hotspots from the Indo-Atlantic and Pacific. However, recent studies show a significant change in the lithospheric net rotation of the O'Neill et al. (2005) model from around $55 \mathrm{Ma}$ (Williams et al., 2015). We suggest that this large change in net rotation could have affected the motion path of the Iceland plume within their model around this crucial time (Fig. 6), during the near-surface arrival of the plume (Sect. 1). Tracking past motions of the Iceland plume remains elusive (O'Neill et al., 2005; Doubrovine et al., 2012; Torsvik et al., 2015; Rogozhina et al., 2016) because thick ice sheets currently cover any potentially preserved geological evidence 


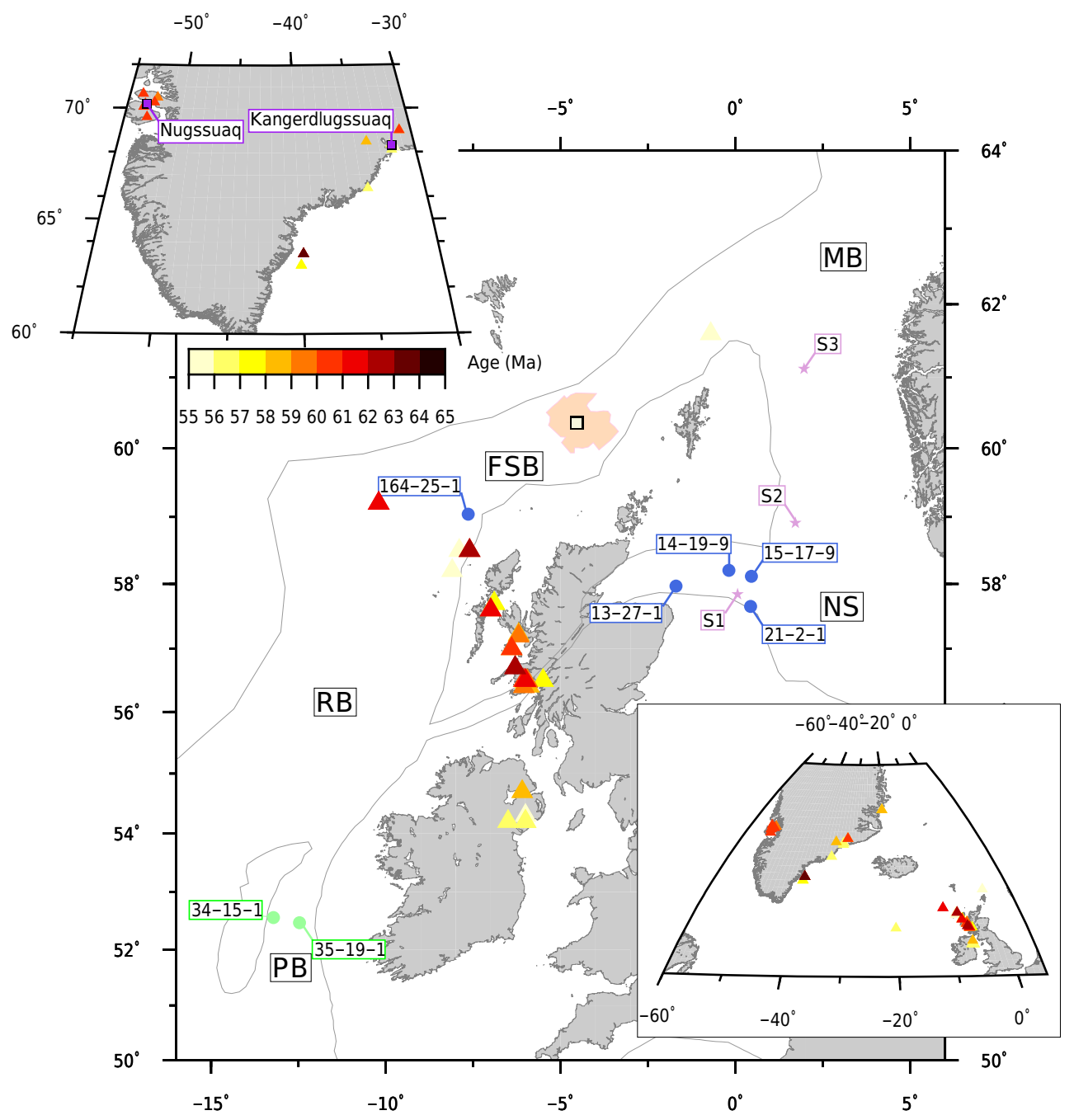

Figure 7. Map view locations of the compiled dataset used to compare against the evolution of model dynamic topography. Solid blue circles: locations of wells that were backstripped for their water-loaded tectonic subsidence histories in Clift and Turner (1998); solid green circles: locations of wells that were backstripped for their water-loaded tectonic subsidence histories in Jones et al. (2001); solid pink stars are locations of modelled stratigraphic cross sections from Nadin et al. (1997); solid beige region represents area of 3-D seismic data coverage used in the analytical modelling approaches of Hartley et al. (2012). Coloured triangles are age-coded plume-related extrusive volcanics from 55 to 65 Ma only (taken from the compilation of Torsvik et al., 2001). MB: Møre Basin; FSB: Faroe-Shetland Basin; RB: Rockall Basin; PB: Porcupine Basin; NS: North Sea. Lower inset shows an overview of the northeastern Atlantic region and the distribution of age-coded plume-related extrusive volcanics. Upper inset shows two additional locations (purple squares) discussed in text on the eastern and western Greenland margins.

of its path beneath Greenland. Therefore, the motion path of the Iceland plume is inferred in any reference frame, based on the fit of other hotspot tracks in either the Indo-Atlantic, or Indo-Atlantic and Pacific, combined with the relative plate circuits chosen for the North Atlantic.

A comparison between the absolute motion path of the model plume and Doubrovine et al. (2012) shows reasonable overall agreement back to $60 \mathrm{Ma}$ (Fig. 6). Both models predict a general west, then southward, absolute motion within the mantle from $60 \mathrm{Ma}$ (Fig. 6). Minor discrepancies between the models concern the timing of this change in di- rection, with the model predicting this to occur at $\sim 40 \mathrm{Ma}$, while Doubrovine et al. (2012) dated this event at $\sim 50 \mathrm{Ma}$. In the plate frame of reference, the general southeast relative motion path of the model plume beneath Greenland exhibits increasing differences as compared with Doubrovine et al. (2012) and O'Neill et al. (2005) for times older than $\sim 40 \mathrm{Ma}$ (Fig. 6); yet, it still generally supports the plume's near-surface arrival beneath eastern Greenland. In the model of Doubrovine et al. (2012) the Iceland plume is located beneath eastern Greenland before $\sim 35 \mathrm{Ma}$ (Fig. 6). Torsvik et al. (2015) state that this is a remarkably good fit given 
the long-term volcanic activity in the immediate vicinity the plume between 30 and $60 \mathrm{Ma}$ (Fig. 6). This observation is consistent with the motion of the model plume, which is also located beneath eastern Greenland before $\sim 35$ Ma (Fig. 6). Torsvik et al. (2015) also note that the unusually thin lithosphere in the region $(<100 \mathrm{~km}$; Rickers et al., 2013) provides further evidence of long-standing plume-lithosphere interactions, as they attribute this thinning to thermal and mechanical erosion (Steinberger et al., 2014) due to the plume head (Torsvik et al., 2015). The large spatial extent of the model plume (Fig. 5c) during its near-surface arrival at $\sim 60 \mathrm{Ma}$ can also account for the contemporaneous eruption of extrusive volcanics along the western Greenland margin and on Baffin Island, which have previously been attributed to the arrival of the Iceland plume (Spice et al., 2016; Stuart et al., 2003; Chalmers et al., 1995).

Comparing the relative motion path of the model plume beneath Greenland to that of O'Neill et al. (2005) shows a general southeastern motion beneath Greenland over the last $60 \mathrm{Myr}$, although the relative motion path of the model plume is further south prior to $\sim 20 \mathrm{Ma}$ (Fig. 6). Rogozhina et al. (2016) used ice-penetrating radar and ice core drilling to identify melting beneath the Greenland Ice Sheet, which they attribute to a large geothermal anomaly beneath Greenland associated with the Iceland plume track between $\sim 80$ and 35 Myr ago (Fig. 6). The moving hotspot path of O'Neill et al. (2005), which is the northernmost of the currently proposed endmember motion paths, best fits that proposed Iceland plume motion path (Rogozhina et al., 2016). This thermal anomaly can be traced continuously westward beneath Baffin Bay and the Davis Straight (Jakovlev et al., 2012), a region that reflects a now extinct seafloor spreading system (Fig. 6; Oakey and Chalmers, 2012). This outlines the difficulty involved in defining the true extent of this thermal anomaly, believed to be reflecting the remnants of the Iceland plume motion path, as its western extent merges into a recently thinned and heated continental margin region (Fig. 6). A recent high-resolution S-velocity model of the North Atlantic region, detailing structural features down to a depth of $1300 \mathrm{~km}$ in the highest resolution to date (Rickers et al., 2013), does not appear to identify any shallow thermal anomaly beneath this region of Greenland. Other geological observations taken from a global compilation indicate that a thick cratonic root exists within southern Greenland (Fig. 6; Artemieva, 2006), which may have played a significant role in plume-lithosphere interactions during the early Cenozoic. The existence of this craton also suggests that the thin thermal anomaly identified by Rogozhina et al. (2016) could represent differences in the geological structures across Greenland rather than the remnants of a plume track. The work of Kaban et al. (2014), who used a numerical approach to decouple the effects of lithospheric plates and the observed geoid globally at present day, indicates that at present day $\sim 500 \mathrm{~m}$ dynamic support across central Greenland is confined to the extent of a "thin finger" traversing from the present-day Iceland plume conduit to Disko Island along central western Greenland (Kaban et al., 2014). Fahnestock et al. (2001) used ice-penetrating radar to reveal that localised regions in southern Greenland undergoing rapid basal melting at present day coinciding with magmatic anomalies and topography associated with volcanic activity (Fahnestock et al., 2001). The extent and magnitude of this basal melt in southern Greenland is in close vicinity of the motion path of the model plume (Fahnestock et al., 2001).

\subsection{Comparing predicted dynamic topography to a compiled set of observables on anomalous uplift and subsidence in the northeastern Atlantic}

\subsubsection{Identifying post-rift anomalous subsidence}

The stretched continental margins of the North Atlantic region reflect major episodes of extension since the late Palaeozoic, which have contributed to the evolution of regional surface topography (Skogseid et al., 2000). The spatial and temporal progression of this continental extension can be understood in terms of evolving patterns of subsidence that reflect rates of crustal thinning and changes in lithospheric heat flow (Jarvis and McKenzie, 1980). During extension the lithosphere thins rapidly, producing rapid subsidence and an accompanying thermal positive anomaly (Jarvis and McKenzie, 1980). Cessation of extension results in the decay of this thermal anomaly due to thermal re-equilibration, reflected in the slowing subsidence rates in accordance with a halfspace cooling model (Jarvis and McKenzie, 1980). As the data compiled in this study is located in major basins across the northeastern Atlantic region (Fig. 7) we used inferred extensional histories of these basins to derive theoretical waterloaded tectonic subsidence histories, identifying any significant deviations from these as anomalous subsidence (Erratt et al., 1999). We compiled data from sites in the Porcupine Basin and North Sea, as well as a location along the western Greenland margin (Fig. 7). As an example of identifying anomalous subsidence we compare water-loaded tectonic subsidence derived from a backstripped well in the North Sea (Fig. 8a; Clift and Turner, 1998) to an expected equivalent water-loaded tectonic subsidence history modelled using a time-dependent analytical approach assuming different stretching factors (Fig. 8a; Jarvis and McKenzie, 1980). Well 13-27-1 (Clift and Turner, 1998) shows a syn-rift stage of subsidence that occurred between 160 and $135 \mathrm{Ma}$ (Fig. 8a). In the absence of control points after this time period we assume a change to post-rift at $\sim 135 \mathrm{Ma}$ (Fig. 8a). During the initial post-rift stages subsidence rates decline until $\sim 100 \mathrm{Ma}$, where an onset in gentle uplift is recorded until $\sim 65 \mathrm{Ma}$. By this time rapid transient uplift occurs (Clift and Turner, 1998), peaking at $\sim 62 \mathrm{Ma}$ and declining by $60 \mathrm{Ma}$, remaining relatively unchanged until present day. In comparison, theoretical tectonic subsidence histories for well 13-271 (Fig. 8a) predict very low post-rift subsidence, declining in 

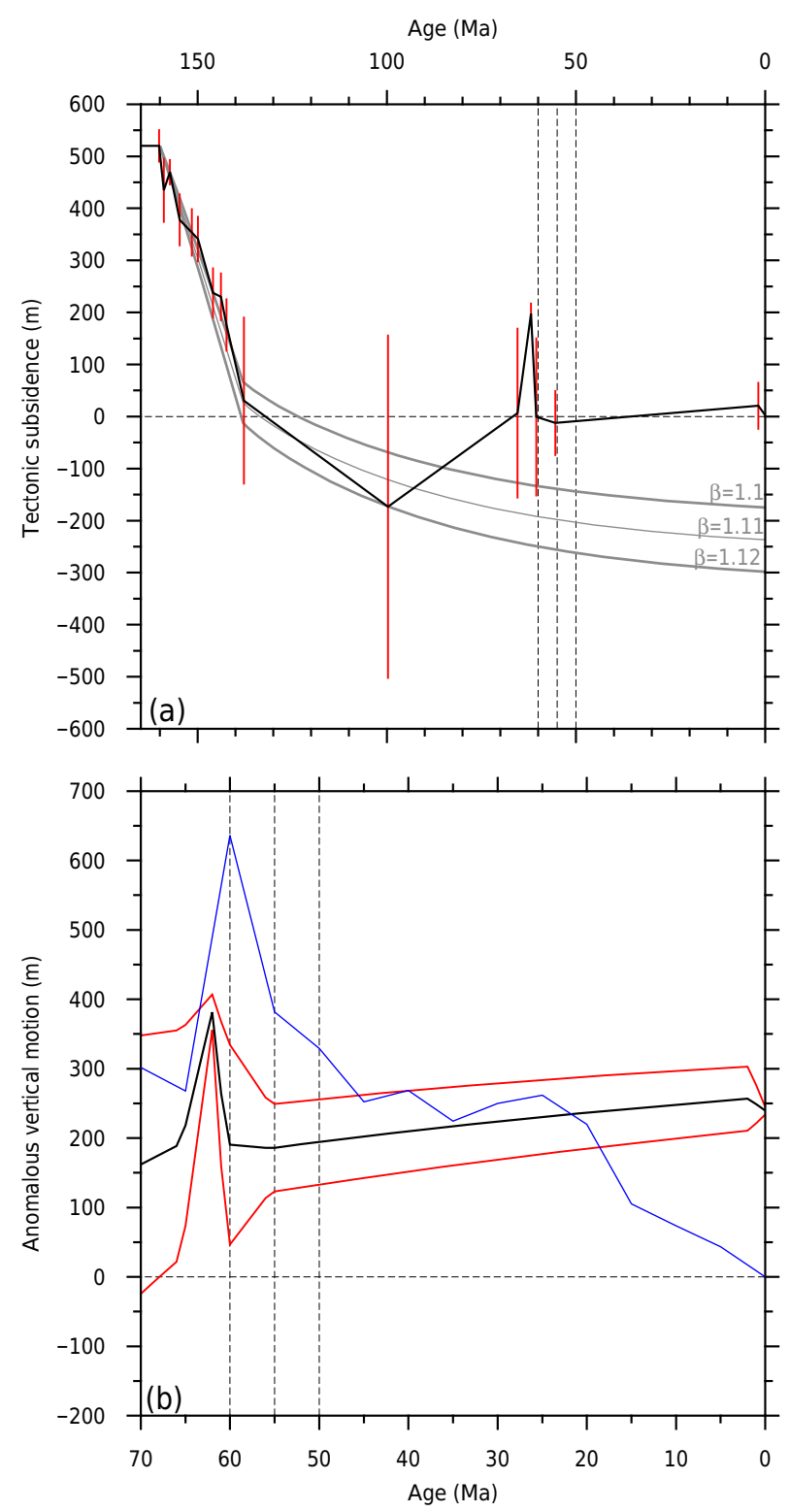

Figure 8. (a) An example of comparing a backstripped waterloaded tectonic subsidence history (solid black curve; Clift and Turner, 1998) against several corresponding modelled water-loaded tectonic subsidence histories (light-grey curves; Jarvis and McKenzie, 1980) from well 13-27-1 in the North Sea. Deviations between these curves can be interpreted as anomalous subsidence inconsistent with expected post-rift thermal subsidence (Jarvis and McKenzie, 1980). Red bars represent errors in subsidence magnitudes related to uncertainties in palaeobathymetry depth estimates (Clift and Turner, 1998). The solid blue curve is the model dynamic topography at this well location (Sect. 2.2.3; Fig. 3). The three vertical lightgrey dotted lines represent ages 60,55 , and $50 \mathrm{Ma}$; the horizontal grey dotted line is zero elevation. (b) Anomalous vertical motion (thick black curve) calculated by subtracting the best-fit modelled tectonic subsidence history $(\beta=1.11)$ away from the subsidence history in (a), focused on the last 70 Myr. Red curves represent errors in anomalous subsidence estimates related to the uncertainty in palaeobathymetry depth mentioned in (a). Thin grey dotted lines and blue curve same as in (a). magnitude throughout the Cenozoic, and continuing like so until present day. The mismatch between predicted and inferred subsidence for this well, with $\sim 400-600 \mathrm{~m}$ less subsidence than predicted at $60 \mathrm{Ma}$ and $\sim 150-350 \mathrm{~m}$ less subsidence than expected at present day and (Fig. 8a), is attributed to the influence of the Iceland plume that is not included in the tectonic subsidence model. Where published well locations have a reasonably good constraint on synrift and postrift stages of a basin, we compute anomalous vertical motion curves that show the differences between the backstripped tectonic subsidence histories and forward-modelled tectonic subsidence history (Figs. 8b, 9g-1). We compute an ideal stretching factor that best matches either the onset in the synrift or post-rift stage, which is then used to calculate the inferred tectonic subsidence history. Differences taken between the two curves represent anomalous vertical motions through time unrelated to thermal cooling of the lithosphere during the post-rift stages (Figs. 8b, 9g-1). In wells appropriate for this calculation across the northeastern Atlantic we focus on anomalous vertical motions for the last $70 \mathrm{Myr}$ only, in accordance with the temporal extent of the dynamic topography model (Sect. 3.2). When using this approach to identify anomalous vertical motions we note that (1) we expect to observe a slow decay in low post-rift subsidence rates during the Cenozoic if extension in a given basin ceased some time during the Cretaceous, (2) we can investigate the spatial and temporal links between modelled anomalous vertical motion curves and the arrival of the Iceland plume (Sect. 3), (3) we can make spatial inferences about the extent of the Iceland plume from the anomalous vertical motions calculated where possible, and (4) we can compare the timing and magnitude of anomalous vertical motion curves with the predicted dynamic topography since the Palaeocene.

\subsubsection{Anomalous vertical motions from wells in the North Sea basins}

In the North Sea published backstripped wells include control points that cover the pre-rift, synrift, and post-rift stages of basin evolution (Fig. 9a-d; Clift and Turner, 1998). Generally, subsidence histories in the region indicate a major phase of extension lasting between $\sim 160$ and $135 \mathrm{Ma}$ (Fig. 9a-d). Following this, each well records a history of post-rift subsidence that is at odds with the theoretical tectonic subsidence curve (Fig. 9; Sect. 4.2.1). As the basins in the North Sea did not experience any secondary extensional episodes after the Late Jurassic (Erratt et al., 1999), we assess the compatibility of the model dynamic topography (Sect. 3.2) with this Cenozoic anomalous subsidence.

In these wells, inferred anomalous subsidence during the Palaeocene may be recorded either as (1) transient uplift between $\sim 65$ and $62 \mathrm{Ma} \mathrm{(13-27-1;} \mathrm{Fig.} \mathrm{9a)} \mathrm{if} \mathrm{enough} \mathrm{control}$ points are available or as (2) anomalous accelerated subsidence from $\sim 60 \mathrm{Ma}$ (14-19-9; Fig. 9b, 21-2-1; Fig. 9c, 1517-9; Fig. 9d). We compare the predicted evolution of dy- 


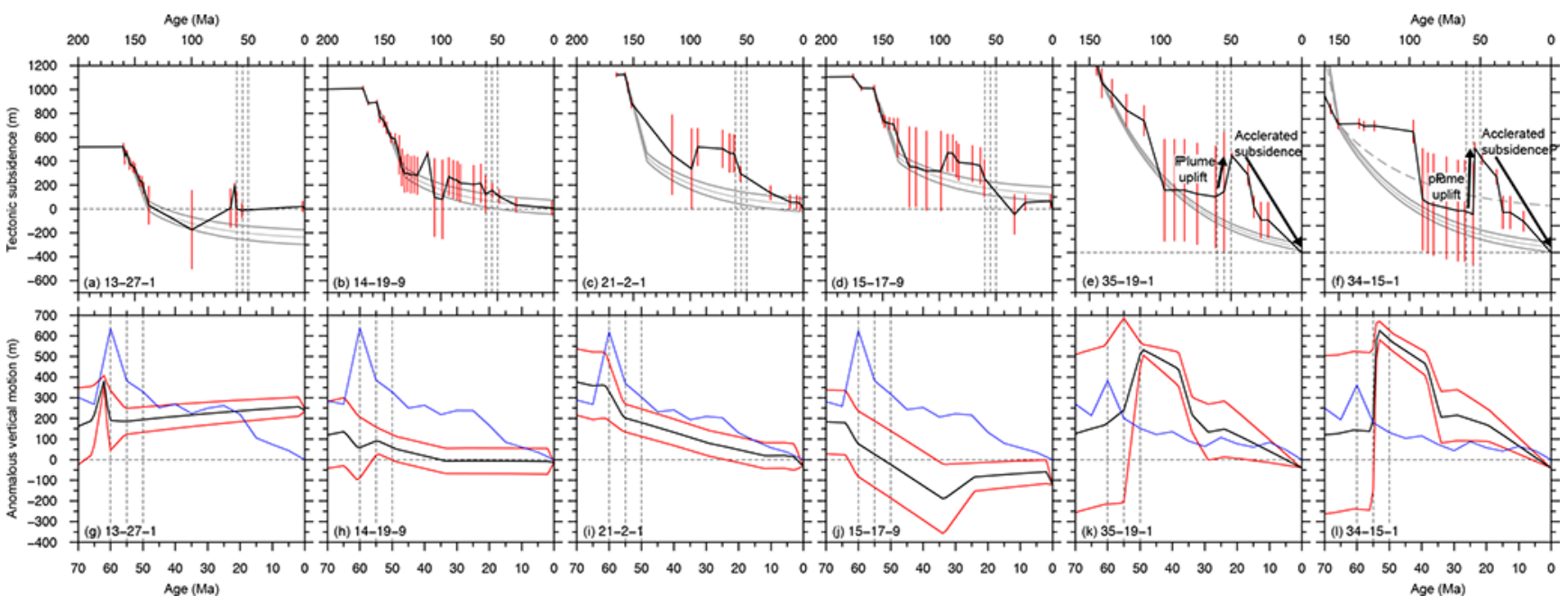

Figure 9. Top panels (a-d): backstripped water-loaded tectonic subsidence histories from wells in the North Sea (locations given in Fig. 6; Clift and Turner, 1998), and Porcupine Basin (e-f; Jones et al., 2001) presented as in Fig. 7a. Bottom panels (g-l): comparison between model dynamic topography and anomalous vertical motion curves presented as in Fig. $7 \mathrm{~b}$ for the last 70 Myr of top panels. Dotted line represents computed theoretical subsidence history from Jones et al. (2001) using their first-choice stretching factor of 1.27 for that particular well.

namic topography for each of these well locations back to $70 \mathrm{Ma}$ to their respective anomalous vertical motions curves computed from the differences between the theoretical and backstripped subsidence histories in Fig. 9g-j (Sect. 4.2.1). Generally, dynamic topography evolves similarly across all well locations, which is to be expected given its spatially long wavelength (e.g. Flament et al., 2013). In this region, the model predicts $\sim 350 \mathrm{~m}$ of dynamic uplift from 65 to $60 \mathrm{Ma}$, then $\sim 250 \mathrm{~m}$ of rapid dynamic subsidence until $55 \mathrm{Ma}$, at which time subsidence of $\sim 100 \mathrm{~m}$ slowly continues until $\sim 35 \mathrm{Ma}$. Following this, $\sim 10-50 \mathrm{~m}$ of dynamic uplift occurs until $\sim 25 \mathrm{Ma}$, then returning to more pronounced dynamic subsidence $(\sim 250 \mathrm{~m})$ until present day. The evolution of model dynamic topography can reasonably explain the timing of anomalous subsidence during the late Palaeocene and early Eocene for wells 13-27-1, 21-2-1 and 15-17-9 (Fig. 9g, i, j). Dynamic topography agrees temporally with the cessation in anomalous uplift by $\sim 60 \mathrm{Ma}$ for well 13 27-1 (Fig. 9g), and with the onset in rapid anomalous subsidence from $\sim 60$ Ma for well 21-2-1 (Fig. 9i). Well 13-271 (Fig. 9g) indicates transient anomalous uplift at $\sim 60 \mathrm{Ma}$, which is temporally offset from our model results by only $\sim 3 \mathrm{Myr}$ (Sect. 4.2.1). The predicted maximum dynamic uplift and subsequent subsidence is overestimated by as much as a factor of 2 at well 14-19-9 (Fig. 9h); however, it is in reasonable agreement at well 21-2-1 (Fig. 9i) and 15-17-9 (Fig. 9j), although with an offset in magnitude at 15-17-9 of $\sim 300 \mathrm{~m}$. This is the result of the normalisation of the dynamic topography signal set to be zero at present day.

Bertram and Milton (1989) derived a basin history at a well in the North Viking Graben, assuming two rifting episodes in the Triassic and Jurassic with a stretching factor of 1.35, and $\sim 300 \mathrm{~m}$ of modelled anomalous Palaeocene uplift (Bertram and Milton, 1989). The evolution of model dynamic topography can explain the timing of this subsidence history. Given that the location of the Viking Graben is in relatively close proximity to the wells analysed from other North Sea basins in Clift and Turner (1998), we use the magnitude of dynamic topography extracted at these well locations as a proxy for the dynamic effect in the North Viking Graben as well. This suggests the dynamic model probably overestimates this anomalous subsidence by a few hundred metres in this basin, too. This Palaeocene transient uplift linked to the Iceland plume is also supported by a Palaeogene unconformity buried by early Eocene deep-water sediments across the North Sea (Mudge and Jones, 2004; Milton et al., 1990) and by pulses of coarse clastic sediment deposited in the northern parts of the North Sea during the earliest Eocene (Huuse, 2002). Nadin et al. (1997) used forward and inverse 2-D modelling of syn- and post-rift stratigraphy to determine the timing and magnitude of Palaeocene uplift associated with the Iceland plume in major basins across this region. They estimated $\sim 375-550 \mathrm{~m}$ of anomalous Palaeocene uplift and computed its thermal decay through time until present day (Fig. 10b) at three locations (Fig. 7; pale purple stars). Comparison of the model dynamic topography extracted at these three points (Fig. 10b) shows agreement in the cessation of dynamic uplift and onset in subsidence at $\sim 60 \mathrm{Ma}$, and an agreement between two of the sites on the total amount of predicted dynamic subsidence from the model since $\sim 60 \mathrm{Ma}$.

In summary, the duration and magnitude of transient uplift and subsidence predicted by the model dynamic topography 


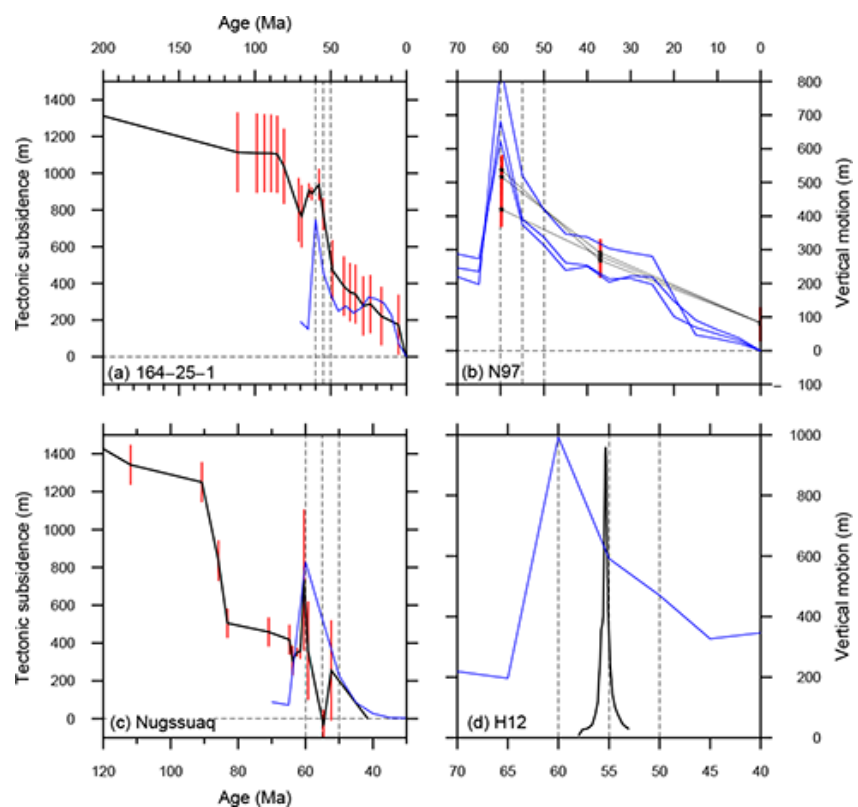

Figure 10. (a) Backstripped water-loaded tectonic subsidence histories for a well in the southern Faroe-Shetland Basin (location given in Fig. 4; Clift and Turner, 1998). (b) Evolution of decaying uplift calculated from modelled stratigraphic sections across the North Sea reproduced from Nadin et al. (1997). Given the long wavelength nature of the model dynamic topography and the relatively close proximity of the three stratigraphic sections (Fig. 6; stars), we include all three results in this plot. Red error bars represent uncertainty in uplift decay over time. The blue curve on each plot is the corresponding time-dependent evolution of dynamic topography (Sect. 2) for each site (Fig. 4). (c) Backstripped water-loaded tectonic subsidence histories for Nugssuaq along the western Greenland margin (Fig. 6) from Clift et al. (1998). Blue dynamic topography curve through time derived as described in Fig. 7. (d) Modelled uplift history from Hartley et al. (2012) - see main text for description.

can be considered reasonable in the context of independent constraints in the North Sea.

\subsubsection{Anomalous vertical motions from wells in the Porcupine Basin}

In the Porcupine Basin we compare two subsidence curves published in Jones et al. (2001) (Fig. 9e-f), as longwavelength dynamic topography is not expected to vary (Flament et al., 2013) over this relatively small basin (Fig. 7). Generally, in this basin post-rift subsidence histories are estimated to indicate $500-800 \mathrm{~m}$ of anomalous transient uplift followed by subsidence since the Palaeocene-Eocene boundary ( $~ 55 \mathrm{Ma}$; Fig. 9k-1; Jones et al., 2001). Similarly to the major basins of the North Sea (Sect. 4.2.2), this basin did not experience any extensional episodes after the Early Cretaceous (Tate et al., 1993), suggesting that the Cenozoic anomalous subsidence recorded in each well across the region is not rift-related. We assess the likelihood that the dynamic topography model (Sect. 3.2) can explain this widespread Palaeocene anomalous subsidence. Temporally, the tectonic subsidence histories commonly show an onset in anomalous transient uplift from $\sim 60$ and $55 \mathrm{Ma}$, and maximum magnitudes peaking at times between $50 \mathrm{Ma}$ (Fig. 9e) and $55 \mathrm{Ma}$ (Fig. 9f). We compute ideal theoretical subsidence histories for each of these wells using the stretching factors and periods published in Jones et al. (2001), and calculate anomalous vertical motion curves as the differences between this inferred subsidence history and the backstripped one (Fig. 9k-1). Generally, these anomalous vertical motion curves show $\sim 300-400 \mathrm{~m}$ of transient uplift followed by $\sim 550-700 \mathrm{~m}$ of anomalous subsidence from $60 \mathrm{Ma}$ (Fig. 9k-1). The maximum model dynamic uplift $(\sim 150 \mathrm{~m}$ at $\sim 60 \mathrm{Ma}$ ) is underpredicted by $\sim 450 \mathrm{~m}$, and the following dynamic subsidence is underpredicted by approximately half of the computed anomalous subsidence. The dynamic uplift predicted in the model beneath this basin is weaker here than in the North Sea basins because the Porcupine Basin is on the southeastern edge of the model plume during the Palaeocene (Fig. 5). However, we suggest caution when interpreting the magnitude of anomalous subsidence computed in Jones et al. (2001). A sensitivity analysis within this study showed that a theoretical subsidence history computed with one stretching event in the Jurassic could fit the backstripped subsidence history, initially estimating $\sim 300 \mathrm{~m}$ of anomalous subsidence (Fig. 9f). Yet, Jones et al. (2001) argued that this theoretical subsidence history underpredicts the observed post-rift subsidence. As a result, they introduce a synthetic layer to represent the eroded syn-rift section to basement, resulting in an increase in their theoretical subsidence and thus estimate of anomalous post-rift subsidence by a factor of nearly 2.5 . Here, the accelerated subsidence computed at each well during the Cenozoic is much larger than the expected response to the transient uplift associated with the arrival of a plume (Fig. 9e-f; Hassan et al., 2015). Therefore, we suggest that other processes known to also be at play during this time could have contributed to this accelerated subsidence, e.g. propagation of intraplate stresses in the region (Nielsen et al., 2007), calling into question the justifications of Jones et al. (2001) to increase their calculated theoretical subsidence histories. We believe their initial fit between the theoretical and backstripped subsidence histories, and consequently much smaller estimates of plume-related anomalous subsidence, is adequate in light of the post-rift subsidence history of this basin being convoluted by other potential processes since the Palaeocene.

This comparison shows the model is reasonably compatible with the duration of Palaeocene transient uplift and subsidence in the Porcupine Basin but underestimates the magnitude of that uplift event and its subsequent subsidence by several hundred metres, which we believe is related to the exclusion of other processes potentially at play, contributing to this post-plume subsidence of this basin. 


\subsubsection{Observations of anomalous vertical motions along the Norwegian margin, eastern and western Greenland margin, and plume-related transient uplift across the remainder of the North Atlantic}

A structural and stratigraphic analysis along the Norwegian margin in the Vøring Basin, immediately north of the Møre Basin (Fig. 7; Planke et al., 1991), showed that its mode of rifting (Peron-Pinvidic et al., 2013) changed from brittle to more ductile extensional deformation during the Palaeocene (Ren et al., 2003). This change is related to the arrival of the Iceland plume, and the subsequent initiation of associated igneous activity (Ren et al., 2003). Roberts et al. (2009) mapped 11 horizons from seabed to base Cretaceous that they backstripped to produce a series of palaeobathymetry and palaeostructure maps across the Møre and Vøring basins. They incorporated a transient dynamic uplift event of the Norwegian margin during the Palaeocene derived from previous estimates made in the Faroe-Shetland Basin (Rudge et al., 2008) as they were unable to distinguish between extension-related and plume-related surface vertical motions within the basins along the Norwegian margin at this time (Roberts et al., 2009, 1997). Nielsen et al. (2002) analysed the topography, heat flow, crustal structure, and Bouger gravity anomaly of Norway, proposing the region was influenced by surface uplift in the latest Palaeocene related to plume emplacement and that its new topography was modulated by changes in climate and eustasy throughout the remaining Cenozoic. Given the current uncertainty in quantifying the magnitude of transient uplift along the Norwegian margin, we are unable to directly assess the model dynamic topography for this region. Nevertheless, the consistency of these observations along the Norwegian margin with those compiled around the remainder of the North Atlantic (Sect. 4.2) is compatible with the spatial and temporal extent of the model plume (Fig. 5). In related studies, Fletcher et al. (2013) used flexural backstripping and decompaction techniques along stratigraphic sections in the Faroe-Shetland Basin (Fig. 5) to estimate $\sim 450-550 \mathrm{~m}$ of late Palaeocene plume-related transient uplift in this basin, providing further evidence of anomalous plume-related topographic motions in the region.

Previous efforts focusing on the sedimentary response of the western and eastern Greenland landscapes to plumedriven uplift used fluvial peneplanation, valley incision, and sediment deposition rates to argue that this uplift was very short lived $(<5 \mathrm{Myr})$ prior to plume eruption, with the uplift of western Greenland quantified at around several hundred metres, and the eastern Greenland uplift unable to be quantified (Dam et al., 1998). Apatite fission track data suggest that the present-day high mountains of western Greenland are erosional remnants of continental uplift during the Neogene (Japsen et al., 2005). However, Redfield (2010) argued that the apatite fission track (AFT) sampling used in this study might be biased. Tectonically, the extensional histories of these margins are temporally offset (Hosseinpour et al., 2013). Along the western Greenland margin continental extension started at $\sim 120 \mathrm{Ma}$ (Hosseinpour et al., 2013), with breakup and seafloor spreading starting in the Labrador Sea at $\sim 60 \mathrm{Ma}$ (Oakey and Chalmers, 2012). Along the eastern Greenland margin, extension started at $\sim 80 \mathrm{Ma}$ (BarnettMoore et al., 2016), and seafloor spreading by $\sim 55 \mathrm{Ma}$ (Skogseid et al., 2000). Based on these extensional histories we expect the slow decay of post-rift subsidence rates to start from continental breakup.

Across the remainder of the North Atlantic we qualitatively compare predicted dynamic topography to several examples of either backstripped water-loaded tectonic subsidence curves (Clift et al., 1998; Clift and Turner, 1998), which preserve evidence of subsidence histories being "interrupted" by anomalous transient uplift during the Palaeocene (Fig. 10a, c), or independent studies that have modelled this plume-related uplift (Fig. 10d). The number of control points used in the construction of the two tectonic subsidence curves used in this comparison is generally small for times older than $\sim 100 \mathrm{Ma}$ (Fig. 10a, c). Therefore, we are unable to produce forward models of these subsidence histories with any real confidence given the lack of well constraints compounded by the complexity in the extensional histories of the basins they are located within (Skogseid et al., 2000; Brekke et al., 2000). Instead, we make a general qualitative comparison between the dynamic model and these subsidence histories, assessing the match between model dynamic topography and the onset and temporal extent of preserved anomalous transient uplift in these basins during the Palaeocene. At well 164-25-1, located in the southern Faroe-Shetland Basin (Fig. 5), maximum uplift occurs at $\sim 58 \mathrm{Ma}$ (Fig. 10a). A comparison with the dynamic uplift predicted from the model shows that plume-related uplift can account for the duration of transient uplift and the timing in peak uplift during the Palaeocene for this well. Along the western Greenland margin at Nugssuaq (Fig. 5), maximum transient uplift occurs first at $\sim 60 \mathrm{Ma}$ followed by a second local maximum at $\sim 53 \mathrm{Ma}$ (Fig. 10c). The post-53 Ma tectonic subsidence histories of this basin are unconstrained (Fig. 10c). The model dynamic topography evolution at this location reflects the close proximity to the near-surface arrival and eastward migration of the model plume through time. At Nugssuaq, the model implies dynamic uplift of $\sim 700 \mathrm{~m}$, commencing from $70 \mathrm{Ma}$ and transitioning to subsidence by $60 \mathrm{Ma}$ (Fig. 10c). This rapid change in significant dynamic uplift is still within the large palaeobathymetric errors margins at peak uplift at $60 \mathrm{Ma}$ (Fig. 10c). In other independent studies, three-dimensional seismic reflection data were used to quantify and temporally constrain the plume-related transient uplift in the Faroe-Shetland Basin (Hartley et al., 2012; Champion et al., 2008; Rudge et al., 2008). Champion et al. (2008) attributed fluvial incisions into marine sediments buried beneath non-marine sediments dated around the Palaeocene-Eocene boundary to transient uplift. Both Rudge et al. (2008) and Champion et al. (2008) estimated $\sim 500 \mathrm{~m}$ 
of uplift that peaked and decayed very quickly over $\sim 3 \mathrm{Myr}$, linking this transient event to the lateral flow of hot material at much shallower mantle depths beneath the lithosphere sourced from a larger mantle anomaly at depth. Hartley et al. (2012) reconstructed an ancient drainage network from three-dimensional seismic data in a similar area of the FaroeShetland Basin, and subsequently inverted these ancient river profiles to derive a surface uplift history. They proposed that this region was uplifted over three discrete steps of 200 $400 \mathrm{~m}$ and then reburied rapidly within $\sim 1 \mathrm{Myr}$ around the Palaeocene-Eocene boundary (Hartley et al., 2012). A comparison between the model and these results shows a mismatch in the timing of maximum transient uplift of $\sim 4$ $5 \mathrm{Myr}$, as the model predicts this to occur earlier at $\sim 60 \mathrm{Ma}$; however, it shows a very reasonable match in magnitudes of uplift around $1000 \mathrm{~m}$ (Fig. 10d). We consider this close match in magnitudes with the study of Hartley et al. (2012) to be more important of the two comparisons made above, given that Hartley et al. (2012) revisited the area studied in Champion et al. (2008). Hartley et al. (2012) proposed that series of hot blobs, sourced from the plume conduit, travelled radially outwards in a horizontal layer in the low-viscosity mantle beneath the lithosphere. They showed that this can be considered geodynamically reasonable in the context of a surface wave tomography model, which images these thermal anomalies maintaining their internal structure up $600 \mathrm{~km}$ from the Iceland plume conduit in the upper mantle beneath the region (Delorey et al., 2007). However, we suggest, based on the evolution of the model plume through time (Fig. 5), that a large component of this transient uplift could be related to the buoyancy forces associated with the near-surface arrival of the Iceland plume from deeper within the mantle. We note that the inversion of this ancient landscape constrains its spatial and temporal evolution of the vertical motion but not its source, and that tomography models do not provide insight to the complex time-dependent evolution of mantle plumes.

In summary, for this set of selective qualitative comparisons across the North Atlantic, the model dynamic topography can explain the duration of Palaeocene anomalous transient uplift. The model also predicts plume-related uplift documented along the Norwegian margin during the Palaeocene; however, current observations do not constrain the magnitude of uplift.

\subsection{Mismatches between the evolution of the model dynamic topography and observational constraints}

Comparing the model dynamic topography to available published geological and geophysical observations (Figs. 710) highlights mismatches in the spatial, temporal, and amplitude evolutions (Sect. 4.2). Temporal mismatches are at most $10 \mathrm{Myr}$ across the North Atlantic (Sect. 4.2). Generally, maximum uplift associated with the near-surface arrival of the Iceland plume is observed to occur sometime in the Palaeocene and early Eocene between $\sim 60-50 \mathrm{Ma}$ (Sect. 4.2; Figs. 7-10), as the model predicts maximum uplift at $\sim 60 \mathrm{Ma}$ across the region (Figs. 7-10). Since the model temporal resolution is $\sim 5 \mathrm{Myr}$ (Sect. 2), this mismatch of up to $\sim 10 \mathrm{Myr}$ in the timing of maximum uplift is not unexpected.

A qualitative comparison between the evolution of dynamic topography amplitudes and the magnitude of preserved anomalous subsidence indicates the model underestimates dynamic uplift by only a few hundred metres (e.g. Porcupine Basin; Sect. 4.2.3). The amplitude of predicted dynamic topography depends on the adopted definition of dynamic topography (e.g. Flament et al., 2013) and boundary conditions for the calculation (e.g. Thoraval and Richards, 1997). Here, we compute water-loaded surface dynamic topography from buoyancy sources deeper than $350 \mathrm{~km}$ and with free-slip boundary conditions. Including shallower buoyancy sources and using no-slip boundary conditions (e.g. Flament et al., 2014) would increase the amplitude of predicted dynamic topography. In addition, the mantle flow models used here do not account for the complex evolution of shallow $(<350 \mathrm{~km})$ asthenospheric flow, or the complex interplay between mantle, lithosphere, and surface processes, which are known to have played an important role in the evolution of the major basins in the North Atlantic following the plume's arrival during the Cenozoic (e.g. Nielsen et al., 2002).

A qualitative comparison between the model dynamic topography and the mapped time-dependent trail of extrusive magmatic rocks constraining the approximate spatial evolution of the plume beneath the North Atlantic suggests the evolution of the model plume beneath the plates can be considered feasible (Fig. 5). The long-wavelength nature of the model dynamic topography results in the gradual dynamic uplift of the northwestern European margin since the midEocene ( $\sim 40 \mathrm{Ma}$ onwards) related to the continued eastward migration, though diminishing spatial extent, of the model plume (Figs. 7-10). This produces a mismatch between the subsidence histories of the Porcupine, Rockall, Faroe-Shetland, Møre, and North Sea basins (except for well 15-17-9; Fig. 9j) and the model dynamic topography evolution, as these basins do not preserve evidence of dynamic uplift from the Eocene until the early Miocene (Figs. 7-10). However, we suggest that the gradual increase in this relatively minor dynamic uplift since this time might be relevant to the current debate surrounding the explanation of observed anomalous Eocene uplift as reviewed in Anell et al. (2009) or younger anomalous uplift in the Neogene (Praeg et al., 2005) across the northeastern Atlantic Ocean.

In summary, this comparison shows the reconstituted dynamic topography model predicts a reasonable spatial and temporal evolution of the Iceland plume, which accounts for contemporaneous Palaeocene vertical motions across the North Atlantic. Mismatches in computed dynamic topography are only a few hundred metres, but given the current 
limitations in the modelling approach and the focus of this study on the deep Earth evolution of the Iceland plume, we consider this to be reasonable.

\section{Conclusions}

Analytics of flow in the lowermost mantle indicate that over the last $\sim 100 \mathrm{Myr}$ a consistent pattern of convergent flow persists in the lowermost mantle near the tip of the African LLSVP, which has remained remarkably stable over this period, making it an ideal plume nucleation site. From a configured space-time evolution of a fully dynamic model plume and its associated dynamic topography we showed reasonable agreement with previous geological models that support the near-surface arrival of the Iceland plume somewhere beneath central eastern Greenland during the Palaeocene and that the inferred motion path of the model plume is also in agreement with the regional volcanic record. A comparison between model dynamic topography and published constraints shows that widespread Palaeocene and early Eocene uplift across the region can be explained by the mantle-driven effects of a large plume $\sim 2500 \mathrm{~km}$ in diameter. In some parts of the North Atlantic the mantle flow model underestimates the magnitude of observed anomalous surface vertical motions during the Palaeocene by a few hundred metres. We suggest that these mismatches in magnitude can be related to the additional effects of shallower upper mantle flow and surface processes responding to those vertical changes, which are not captured in the modelling approach.

\section{Data availability}

The data used to generate Fig. 1 can be found via the in-text citation. All data used in this study to generate the remaining figures are freely available upon request by contacting the corresponding author at nicholas.barnett-moore@sydney.edu.au, or try n_barnettmoore@hotmail.com.

\section{Information about the Supplement}

Animation S1: Evolution of the model plume since eruption at $150 \mathrm{Ma}$ to present day - see Fig. 3 for details.

\section{The Supplement related to this article is available online at doi:10.5194/se-8-235-2017-supplement.}

Competing interests. The authors declare that they have no conflict of interest.
Acknowledgements. This research was undertaken with the assistance of resources from the National Computational Infrastructure (NCI), which is supported by the Australian Government. The authors were supported by Australian Research Council grants IH130200012 and DP130101946. We thank an anonymous reviewer and Alexander Koptev for very helpful suggestions that improved the manuscript during the review process. Figures were constructed using the Generic Mapping Tools and Python libraries.

Edited by: T. Gerya

Reviewed by: A. Koptev and one anonymous referee

\section{References}

Anell, I., Thybo, H., and Artemieva, I.: Cenozoic uplift and subsidence in the North Atlantic region: geological evidence revisited, Tectonophysics, 474, 78-105, 2009.

Artemieva, I. M.: Global $1 \times 1$ thermal model TC1 for the continental lithosphere: implications for lithosphere secular evolution, Tectonophysics, 416, 245-277, 2006.

Barnett-Moore, N., Müller, R. D., Williams, S., Skogseid, J., and Seton, M.: A reconstruction of the North Atlantic since the earliest Jurassic, Basin Res., 1-26, doi:10.1111/bre.12214, 2016.

Bertram, G. and Milton, N.: Reconstructing basin evolution from sedimentary thickness; the importance of palaeobathymetric control, with reference to the North Sea, Basin Res., 1, 247-257, 1988.

Bower, D. J., Gurnis, M., and Seton, M.: Lower mantle structure from paleogeographically constrained dynamic Earth models, Geochem. Geophy. Geosy., 14, 44-63, 2013.

Bower, D. J., Gurnis, M., and Flament, N.: Assimilating lithosphere and slab history in 4-D Earth models, Phys. Earth Planet. In., 238, 8-22, 2015.

Boyden, J. A., Müller, R. D., Gurnis, M., Torsvik, T. H., Clark, J. A., Turner, M., Ivey-Law, H., Watson, R. J., and Cannon, J. S.: Next-generation plate-tectonic reconstructions using GPlates, Geoinformatics, cyberinfrastructure for the solid earth sciences, 95-114, 2011.

Brekke, H.: The tectonic evolution of the Norwegian Sea continental margin, with emphasis on the Voring and More basins, Special Publication-Geol. Soc. London, 167, 327-378, 2000.

Burke, K., Steinberger, B., Torsvik, T. H., and Smethurst, M. A.: Plume generation zones at the margins of large low shear velocity provinces on the core-mantle boundary, Earth Planet. Sc. Lett., 265, 49-60, 2008.

Chalmers, J., Larsen, L., and Pedersen, A.: Widespread Palaeocene volcanism around the northern North Atlantic and Labrador Sea: evidence for a large, hot, early plume head, J. Geol. Soc. London, 152, 965-969, 1995.

Champion, M., White, N., Jones, S., and Lovell, J.: Quantifying transient mantle convective uplift: An example from the Faroe-Shetland basin, Tectonics, 27, 1-18, doi:10.1029/2007TC002106, 2008.

Christensen, U. R. and Yuen, D. A.: Layered convection induced by phase transitions, J. Geophys. Res.-Sol. Ea., 90, 10291-10300, 1985. 
Clift, P.: Plume tectonics as a cause of mass wasting on the southeast Greenland continental margin, Mar. Petrol. Geol., 13, 771-780, 1996.

Clift, P. D. and Turner, J.: Dynamic support by the Icelandic plume and vertical tectonics of the northeast Atlantic continental margins, J. Geophys. Res.-Sol. Ea., 100, 24473-24486, 1995.

Clift, P. D. and Turner, J.: Paleogene igneous underplating and subsidence anomalies in the Rockall-Faeroe-Shetland area, Mar. Petrol. Geol., 15, 223-243, 1998.

Clift, P., Carter, A., and Hurford, A.: The erosional and uplift history of NE Atlantic passive margins: constraints on a passing plume, J. Geol. Soc., 155, 787-800, 1998.

Conrad, C. P. and Gurnis, M.: Seismic tomography, surface uplift, and the breakup of gondwanaland: Integrating mantle convection backwards in time, Geochem. Geophy. Geosy., 4, 1031, doi:10.1029/2001GC000299, 2003.

Crosby, A. and McKenzie, D.: An analysis of young ocean depth, gravity and global residual topography, Geophys. J. Int., 178, 1198-1219, 2009.

Dam, G., Larsen, M., and Sønderholm, M.: Sedimentary response to mantle plumes: implications from Paleocene onshore successions, West and East Greenland, Geology, 26, 207-210, 1998.

Delorey, A. A., Dunn, R. A., and Gaherty, J. B.: Surface wave tomography of the upper mantle beneath the Reykjanes Ridge with implications for ridge-hot spot interaction, J. Geophys. Res., 112, B08313, doi:10.1029/2006JB004785, 2007.

Doubrovine, P. V., Steinberger, B., and Torsvik, T. H.: Absolute plate motions in a reference frame defined by moving hot spots in the Pacific, Atlantic, and Indian oceans, J. Geophys. Res.-Sol. Ea., 117, B09101, doi:10.1029/2011JB009072, 2012.

Doubrovine, P. V., Steinberger, B., and Torsvik, T. H.: A failure to reject: Testing the correlation between large igneous provinces and deep mantle structures with EDF statistics, Geochem. Geophy. Geosy., 17, 1130-1163, 2016.

Erratt, D., Thomas, G., and Wall, G.: The evolution of the central North Sea Rift, in: Proceedings Geological Society, London, Petroleum Geology Conference series, Geological Society of London, 5, 63-82, 1999.

Fahnestock, M., Abdalati, W., Joughin, I., Brozena, J., and Gogineni, P.: High geothermal heat flow, basal melt, and the origin of rapid ice flow in central Greenland, Science, 294, 2338-2342, 2001.

Flament, N., Gurnis, M., and Müller, R. D.: A review of observations and models of dynamic topography, Lithosphere, 5, 189210, 2013.

Flament, N., Gurnis, M., Williams, S. E., Seton, M., Skogseid, J., Heine, C., and Müller, R. D.: Topographic asymmetry of the South Atlantic from global models of mantle flow and lithospheric stretching, Earth Planet. Sc. Lett., 387, 107-119, doi:10.1016/j.epsl.2013.11.017, 2014.

Fletcher, R., Kusznir, N., Roberts, A., and Hunsdale, R.: The formation of a failed continental breakup basin: The Cenozoic development of the Faroe-Shetland Basin, Basin Res., 25, 532-553, 2013.

French, S. W. and Romanowicz, B.: Broad plumes rooted at the base of the Earth's mantle beneath major hotspots, Nature, 525, 95-99, 2015.
Green, P. F.: Early Tertiary paleo-thermal effects in Northern England: reconciling results from apatite fission track analysis with geological evidence, Tectonophysics, 349, 131-144, 2002.

Hartley, R. A., Roberts, G. G., White, N., and Richardson, C.: Transient convective uplift of an ancient buried landscape, Nat. Geosci., 4, 562-565, 2012.

Hassan, R., Flament, N., Gurnis, M., Bower, D. J., and Müller, D.: Provenance of plumes in global convection models, Geochem. Geophy. Geosy., 16, 1465-1489, 2015.

Hassan, R., Müller, R. D., Gurnis, M., Williams, S. E., and Flament, N.: A rapid burst in hotspot motion through the interaction of tectonics and deep mantle flow, Nature, 533, 239-242, 2016.

He, Y., Wen, L., Capdeville, Y., and Zhao, L.: Seismic evidence for an Iceland thermo-chemical plume in the Earth's lowermost mantle, Earth Planet. Sc. Lett., 417, 19-27, 2015.

Hosseinpour, M., Müller, R. D., Williams, S. E., and Whittaker, J. M.: Full-fit reconstruction of the Labrador Sea and Baffin Bay, Solid Earth, 4, 461-479, doi:10.5194/se-4-461-2013, 2013.

Huuse, M.: Cenozoic uplift and denudation of southern Norway: insights from the North Sea Basin, Geol. Soc. Spec. Publ., 196, 209-233, 2002.

Ismail-Zadeh, A., Korotkii, A., Schubert, G., and Tsepelev, I.: Numerical techniques for solving the inverse retrospective problem of thermal evolution of the Earth interior, Comput. Struct., 87, 802-811, 2009.

Jakovlev, A., Bushenkova, N., Koulakov, I. Y., and Dobretsov, N.: Structure of the upper mantle in the Circum-Arctic region from regional seismic tomography, Russ. Geol. Geophys., 53, 963971, 2012.

Japsen, P., Green, P. F., and Chalmers, J. A.: Separation of Palaeogene and Neogene uplift on Nuussuaq, West Greenland, J. Geol. Soc. London, 162, 299-314, 2005.

Jarvis, G. T. and McKenzie, D. P.: Sedimentary basin formation with finite extension rates, Earth Planet. Sc. Lett., 48, 42-52, 1980.

Jones, S. M., White, N., and Lovell, B.: Cenozoic and Cretaceous transient uplift in the Porcupine Basin and its relationship to a mantle plume, Geol. Soc. Spec. Publ., 188, 345-360, 2001.

Joy, A. M.: Right place, wrong time: anomalous post-rift subsidence in sedimentary basins around the North Atlantic Ocean, Geol. Soc. Spec. Publ., 68, 387-393, 1992.

Kaban, M. K., Petrunin, A. G., Schmeling, H., and Shahraki, M.: Effect of decoupling of lithospheric plates on the observed geoid, Surv. Geophys., 35, 1361-1373, 2014.

Karato, S. and Wu, P.: Rheology of the upper mantle - A synthesis, Science, 260, 771-778, 1993.

Lekic, V., Cottar, S., Dziewonski, A., and Romanowicz, B.: Cluster analysis of global lower mantle tomography: A new class of structure and implications for chemical heterogeneity, Earth Planet. Sc. Lett., 357, 68-77, 2012.

Lewis, C. L., Green, P. F., Carter, A., and Hurford, A. J.: Elevated K/T palaeotemperatures throughout Nortwest England: three kilometres of Tertiary erosion?, Earth Planet. Sc. Lett., 112, 131-145, 1992.

McNamara, A. K. and Zhong, S.: Thermochemical structures within a spherical mantle: Superplumes or piles?, J. Geophys. Res.-Sol. Ea., 109, B07402, doi:10.1029/2003JB002847, 2004. 
Milton, N., Bertram, G., and Vann, I.: Early Palaeogene tectonics and sedimentation in the Central North Sea, Geol. Soc. Spec. Publ., 55, 339-351, 1990.

Moucha, R. and Forte, A. M.: Changes in african topography driven by mantle convection, Nat. Geosci., 4, 707-712, 2011.

Morgan, W. J.: Convection plumes in the lower mantle, Nature, 230, 42-43, doi:10.1038/230042a0, 1971.

Mudge, D. C. and Jones, S. M.: Palaeocene uplift and subsidence events in the Scotland-Shetland and North Sea region and their relationship to the Iceland Plume, J. Geol. Soc. London, 161, 381-386, 2004.

Müller, R. D., Royer, J.-Y., and Lawver, L. A.: Revised plate motions relative to the hotspots from combined Atlantic and Indian Ocean hotspot tracks, Geology, 21, 275-278, 1993.

Nadin, P., Kusznir, N., and Toth, J.: Transient regional uplift in the Early Tertiary of the northern North Sea and the development of the Iceland Plume, J. Geol. Soc., 152, 953-958, 1995.

Nadin, P., Kusznir, N., and Cheadle, M.: Early Tertiary plume uplift of the North Sea and Faeroe-Shetland basins, Earth Planet. Sc. Lett., 148, 109-127, 1997.

Nielsen, S., Paulsen, G., Hansen, D., Gemmer, L., Clausen, O., Jacobsen, B., Balling, N., Huuse, M., and Gallagher, K.: Paleocene initiation of Cenozoic uplift in Norway, Geol. Soc. Spec. Publ., 196, 45-65, 2002.

Nielsen, S. B., Stephenson, R., and Thomsen, E.: Dynamics of MidPalaeocene North Atlantic rifting linked with European intraplate deformations, Nature, 450, 1071-1074, 2007.

Noble, R., Macintyre, R., and Brown, P.: Age constraints on Atlantic evolution: timing of magmatic activity along the E Greenland continental margin, Geol. Soc. Spec. Publ., 39, 201-214, 1988 ,

Oakey, G. N. and Chalmers, J. A.: A new model for the Paleogene motion of Greenland relative to North America: plate reconstructions of the Davis Strait and Nares Strait regions between Canada and Greenland, J. Geophys. Res.-Sol. Ea., 117, B10401, doi:10.1029/2011JB008942, 2012.

O’Neill, C., Müller, D., and Steinberger, B.: On the uncertainties in hot spot reconstructions and the significance of moving hot spot reference frames, Geochem. Geophy. Geosy., 6, Q04003, doi:10.1029/2004GC000784, 2005.

Parnell-Turner, R., White, N., Henstock, T., Murton, B., Maclennan, J., and Jones, S. M.: A continuous 55-million-year record of transient mantle plume activity beneath Iceland, Nat. Geosci., 7, 914-919, 2014.

Peron-Pinvidic, G., Manatschal, G., and Osmundsen, P. T.: Structural comparison of archetypal Atlantic rifted margins: a review of observations and concepts, Mar. Petrol. Geol., 43, 21-47, 2013.

Planke, S., Skogseid, J., and Eldholm, O.: Crustal structure off Norway, 62 to 70 north, Tectonophysics, 189, 91-107, 1991.

Praeg, D., Stoker, M., Shannon, P., Ceramicola, S., Hjelstuen, B., Laberg, J., and Mathiesen, A.: Episodic Cenozoic tectonism and the development of the NW European "passive" continental margin, Mar. Petrol. Geol., 22, 1007-1030, 2005.

Redfield, T.: On apatite fission track dating and the Tertiary evolution of West Greenland topography, J. Geol. Soc. London, 167, 261-271, 2010.
Ren, S., Faleide, J. I., Eldholm, O., Skogseid, J., and Gradstein, F.: Late Cretaceous-Paleocene tectonic development of the NW Vøring basin, Mar. Petrol. Geol., 20, 177-206, 2003.

Rickers, F., Fichtner, A., and Trampert, J.: The Iceland-Jan Mayen plume system and its impact on mantle dynamics in the North Atlantic region: evidence from full-waveform inversion, Earth Planet. Sc. Lett., 367, 39-51, 2013.

Roberts, A. M., Lundin, E. R., and Kusznir, N. J.: Subsidence of the Vøring Basin and the influence of the Atlantic continental margin, J. Geol. Soc. London, 154, 551-557, 1997.

Roberts, A. M., Corfield, R. I., Kusznir, N. J., Matthews, S. J., Hansen, E.-K., and Hooper, R. J.: Mapping palaeostructure and palaeobathymetry along the Norwegian Atlantic continental margin: Møre and Vøring basins, Petrol. Geosci., 15, 27-43, 2009.

Rogozhina, I., Petrunin, A. G., Vaughan, A. P., Steinberger, B., Johnson, J. V., Kaban, M. K., Calov, R., Rickers, F., Thomas, M., and Koulakov, I.: Melting at the base of the Greenland ice sheet explained by Iceland hotspot history, Nat. Geosci., 9, 366-369, doi:10.1038/NGEO2689, 2016.

Rost, S. and Earle, P.: Identifying regions of strong scattering at the core-mantle boundary from analysis of PKKP precursor energy, Earth Planet. Sc. Lett., 297, 616-626, 2010.

Rudge, J. F., Champion, M. E. S., White, N., McKenzie, D., and Lovell, B. A plume model of transient diachronous uplift at the Earth's surface, Earth Planet. Sc. Lett., 267, 146-160, 2008.

Saunders, A. , Fitton, J. G., Kerr, A. C., Norry, M. J., and Kent, R. W.: The North Atlantic Igneous Province, in: Large Igneous Provinces: Continental, Oceanic, and Planetary Flood Volcanism, edited by: Mahoney, J. J. and Coffin, M. F., American Geophysical Union, Washington, D.C., doi:10.1029/GM100p0045, 1997.

Saunders, A. D., Larsen, H. C., and Fitton, J. G.: Magmatic development of the southeast Greenland margin and evolution of the Iceland Plume: Geochemcial constraints from IODP Leg, Proceedings of the Ocean Drilling Program, Scientific results, 152, 1998.

Skogseid, J., Planke, S., Faleide, J. I., Pedersen, T., Eldholm, O., and Neverdal, F.: NE Atlantic continental rifting and volcanic margin formation, Geol. Soc. Spec. Publ., 167, 295-326, 2000.

Smallwood, J. and White, R.: Ridge-plume interaction in the North Atlantic and its influence on continental breakup and seafloor spreading, Geol. Soc. Spec. Publ., 197, 15-37, 2002.

Smallwood, J. R. and Gill, C. E.: The rise and fall of the FaroeShetland Basin: evidence from seismic mapping of the Balder Formation, J. Geol. Soc. London, 159, 627-630, 2002.

Spice, H. E., Fitton, J. G., and Kirstein, L. A.: Temperature fluctuation of the Iceland mantle plume through time, Geochem. Geophy. Geosy., 17, 243-254, doi:10.1002/2015GC006059, 2016.

Steinberger, B.: Plumes in a convecting mantle: Models and observations for individual hotspots, J. Geophys. Res.-Sol. Ea., 105, 11127-11152, 2000.

Steinberger, B. and Calderwood A. R.: Models of large-scale viscous flow in the Earth's mantle with constraints from mineral physics and surface observations, Geophys. J. Int., 167, 14611481, 2006.

Steinberger, B., Spakman, W., Japsen, P., and Torsvik, T. H.: The key role of gloabel solid-Earth processes in preconditioning Greenland's glaciation since the Pliocene, Terra Nova, 27, 1-8, 2014. 
Stoker, M.: Mid-to late Cenozoic sedimentation on the continental margin off NW Britain, J. Geol. Soc. London, 154, 509-515, 1997.

Storey, M., Duncan, R. A., and Tegner, C.: Timing and duration of volcanism in the North Atlantic Igneous Province: Implications for geodynamics and links to the Iceland hotspot, Chem. Geol., 241, 264-281, 2007.

Stuart, F. M., Lass-Evans, S., Fitton, J. G., and Ellam, R. M.: High $3 \mathrm{He} / 4 \mathrm{He}$ ratios in picritic basalts from Baffin Island and the role of a mixed reservoir in mantle plumes, Nature, 424, 57-59, 2003.

Tackley, P. J.: Effects of strongly variable viscosity on three dimensional compressible convection in planetary mantles, J. Geophys. Res.-Sol. Ea., 101, 3311-3332, 1996.

Tate, M., White, N., and Conroy, J. J.: Lithospheric extension and magmatism in the Porcupine Basin west of Ireland, J. Geophys. Res.-Sol. Ea., 98, 13905-13923, 1993.

Tegner, C., Brooks, C., Duncan, R., Heister, L., and Bernstein, S.: $40 \mathrm{Ar}-39 \mathrm{Ar}$ ages of intrusions in East Greenland: Rift-to-drift transition over the Iceland hotspot, Lithos, 101, 480-500, 2008.

Torsvik, T. H., Mosar, J., and Eide, E. A.: Cretaceous-tertiary geodynamics: a North Atlantic exercise, Geophys. J. Int., 146, 850866, 2001.

Torsvik, T. H., Amundsen, H. E., Trønnes, R. G., Doubrovine, P. V., Gaina, C., Kusznir, N. J., Steinberger, B., Corfu, F., Ashwal, L. D., and Griffin, W. L.: Continental crust beneath southeast Iceland, P. Natl. Acad. Sci. USA, 112, E1818-E1827, 2015.
Tosi, N., Yuen, D. A., De Koker, N., and Wentzcovitch, R. M.: Mantle dynamics with pressure-and temperature-dependent thermal expansivity and conductivity, Phys. Earth Planet. In., 217, 48$58,2013$.

Thoraval, C. and Richards, M. A.: The geoid constraint in global geodynamics: viscosity structure, mantle heterogeneity models and boundary conditions, Geophys. J. Int., 131, 1-8, 1997.

Upton, B., Emeleus, C., Rex, D., and Thirlwall, M.: Early tertiary magmatism in NE Greenland, J. Geol. Soc. London, 152, 959964, 1995.

Wessel, P., Smith, W. H., Scharroo, R., Luis, J., and Wobbe, F.: Generic Mapping Tools: Improved Version Released: Eos, Transactions American Geophysical Union, 94, 409-410, 2013.

White, R. and McKenzie, D.: Magmatism at rift zones: the generation of volcanic continental margins and flood basalts, J. Geophys. Res.-Sol. Ea., 94, 7685-7729, 1989.

White, R., Bown, J., and Smallwood, J.: The temperature of the Iceland plume and origin of outward-propagating V-shaped ridges, J. Geol. Soc. London, 152, 1039-1045, 1995.

Williams, S., Flament, N., Müller, R. D., and Butterworth, N.: Absolute plate motions since 130 Ma constrained by subduction zone kinematics, Earth Planet. Sc. Lett., 418, 66-77, 2015.

Zhong, S., Mcnamara, A., Tan, E., Moresi, L., and Gurnis, M.: A benchmark study on mantle convection in a 3-D spherical shell using CitcomS, Geochem. Geophy. Geosy., 9, Q10017, doi:10.1029/2008GC002048, 2008. 